\title{
Going global: differential accumulation and the great U-turn in South Africa and Israel
}

\author{
Jonathan Nitzan ${ }^{\mathrm{a}, *}$, Shimshon Bichler ${ }^{\mathrm{b}}$ \\ ${ }^{a}$ York University, Political Science, 4700 Keele Street, North York, Ontario M3J 1P3, Canada \\ ${ }^{\mathrm{b}} \mathrm{POB}$ 4283, Jerusalem, 91-042, Israel
}

Received 19 March 1998; accepted 1 August 1999

\begin{abstract}
This paper offers a new theoretical approach for comparing the current political-economic U-turns in South Africa and Israel. Our principal focus is on a revised notion of capital, emphasizing the central role of differential accumulation by dominant capital groups. We further distinguish between an antagonistic "depth" regime in which differential accumulation is achieved via stagflation, and a less conflictual "breadth" regime where redistribution occurs through growth. Within this framework, we argue that both the recent transition in the two countries, as well as their former regimes, were greatly affected by global developments. Until the 1980s, accumulation in both countries depended largely on depth, characterized by a marked disparity between deepening crisis on the one hand, and rapid differential accumulation on the other. In South Africa, the large companies benefited disproportionately from the impact on gold profit of global inflation, and were therefore reluctant to abandon apartheid. Similarly, Israel's leading firms recorded spectacular gains riding the global arms race and regional conflict, and hence voiced little opposition to the continuation of a war economy at home. Recently, however, these global forces went into reverse, triggering in both countries a shift from depth to breadth. The disinflation associated with rapid globalization undermined gold profit in South Africa, while the end of the Cold War pulled the rug from under the global arms race, drying up the flow of war profit in Israel. In these new conditions, dominant capital groups in the two countries can sustain their differential accumulation only by investing outside their own borders. Capital mobility, though, requires political-economic stability, hence the support of these groups for democracy in South Africa and to regional reconciliation in Israel. (C) 2001 URPE. All rights reserved.
\end{abstract}

* Corresponding author.

E-mail addresses: nitzan@yorku.ca (J. Nitzan), tookie@inter.net.il (S. Bichler). 
JEL classification: $\mathrm{O} 23 ; \mathrm{O} 57$

Keywords: South Africa; Israel; Differential accumulation; Globalization

\section{Introduction and overview}

South Africa and Israel share many historical similarities. Both countries were founded by white minorities through planned colonization; both were considered strategic assets for the British empire; after World War II, both adopted a pro-American foreign policy; in both countries the elites perceived their societies as islands of Western culture in the midst of a backward, hostile environment; both had similar economic institutions - highly oligopolistic market structures, heavy government involvement, and rigid labor market segmentation along racial/ethnic lines; finally, the economic development of both countries, particularly since the 1960s, has unfolded within the framework of a "war economy," with recurring armed conflicts, large military and internal security budgets, and major weapon development programs.

Since the late 1980s, South Africa and Israel have undergone profound and surprisingly similar U-turns, affecting the very nature and direction of their political-economic regimes. Politically, both shifted toward a nonconfrontational foreign policy while recognizing the legitimacy of long-term internal enemies-the ANC and the PLO. Economically, both abandoned the corporatist model in favor of market reform, liberalization, free trade, and foreign investment. In both cases, the transition stands to undermine middle strata which until recently supported the racist/statist consensus.

Why has this U-turn taken place? To what extent can the similarities between the two countries account for their parallel transitions? What was the role of ethnic conflict and economic crisis? Why were the two transitions relatively peaceful? How is this transformation related to the broader process of liberalization and democratization affecting many other peripheral countries? Where is the new order heading?

The purpose of this paper is to offer a new analytical framework in which these questions can be addressed. The thrust of our argument is twofold. First, we argue that in both cases the U-turn should be understood as part of a broader, global transformation. Second, we claim that the central moment of this transformation, globally as well as domestically, is the changing nature of capital accumulation.

The analytical framework is based on our concept of "differential accumulation," which contrary to conventional practice, measures the augmentation of capital in relative, not absolute terms. For modern absentee owners, the goal is not to maximize profit, but to "beat the average" by raising profit faster than other owners. Differential accumulation indicators shed new light on the experience of the two countries, showing that although their societies entered a crisis as early as the 1960s and 1970s, their capitalist elites started to feel the pinch only in the 1980s, when their differential performance turned negative. It was only then that the new order began in earnest.

The rise and fall of differential accumulation domestically was rooted in broader changes affecting the pattern of global differential accumulation. During much of the postwar period, 
Western countries operated in the "closed" context of a bi-polar war economy. The initial boom enabled large Western companies to accumulate through differential growth, or "breadth." But when growth began to subside, differential accumulation shifted to "depth," with redistribution operating mainly through inflation and military spending. The global depth regime had a profound impact on domestic accumulation in both South Africa and Israel. For South Africa, global inflation helped provide the last kick for a declining gold economy, postponing the final disintegration of apartheid. For Israel, superpower confrontation over Middle East oil helped underwrite a war economy based on US assistance and intense internal redistribution.

The 1980s marked another global watershed. Following the collapse of Communism, the focus of differential accumulation switched back from depth to breadth. The principal way to beat the average now is to expand market share, with the main targets-despite their recent crisis-being the so-called emerging markets and the transition economies of the former Communist bloc. And here too, the consequences for differential accumulation in South Africa and Israel have been profound. Falling inflation in the Western countries undermined gold earnings in South Africa, while the end of the Cold War liquidated the military economy in Israel. The large domestic firms in these two countries could renew their differential accumulation only by accepting the new world order and "going global," a trajectory which mandates a shift to democracy in South Africa and to peace in the Middle East.

Significant social change is never monocausal, of course, and there is no attempt here to portray accumulation in general and differential accumulation in particular as deterministic forces. Obviously, many other factors and processes were involved in those great U-turns. Our claim is rather that these can be better understood within the context of accumulation. As the central process of capitalism, accumulation shapes or delimits the boundaries of change; it sets the "limits of the possible," not its precise path; it tells us what can happen, but not whether it will, when, and how. It is also important to note that, as a social process, accumulation is in fact much broader than is commonly assumed. Indeed, the progressive commodification of social relations implies that many diverse phenomena-ranging from military conflict, through popular revolt, to ethnic and racial tension, international sanctions, crime, socialization, brainwashing, and so on-are increasingly perceived, particularly by capitalist elites, in terms of their impact on the "bottom line"; in other words, they are viewed not "for what they are" but as facets of accumulation. For these reasons, our focus on accumulation in this article is in fact both loose in its delineation of historical change, as well as encompassing of many social processes through their impact on profit and distribution.

\section{Existing studies}

Most comparative studies of South Africa and Israel tend to stress ethnicity as the root cause of their respective conflicts. This approach, however popular, fails to deal with broader issues of political economy, and is therefore insufficient. Recent works have begun dealing with such issues, trying to understand ethnicity as part of a wider political-economic process, 
though here too there are problems, particularly in the treatment of accumulation and the global role of the two countries.

According to the "ethnic school," the history of both countries has been dominated by ethnic-cultural conflict (Greenstein, 1995). The standard pattern of such conflict, common to many other colonial societies, starts with a territorial dispute in which a European minority gains the upper hand, and ends in an inevitable cycle of domination, exploitation, appropriation, and in some cases expulsion of local populations (Kuper, 1971). Writers who compared South Africa and Israel often noted particular similarities-for instance, the emphasis on racial segregation embedded in Jewish-Christian culture (Stevens, 1976); the parallels between land and labor policies toward the Palestinians in Israel and toward nonwhites in South Africa (McTague, 1985); security cooperation between the two countries (Barnaby, 1989; Beith Hallahmi, 1987); and of course their massive popular uprisings in the 1980s. The resolution of the two conflicts has also been linked to ethnicity. According to Smooha and Hanf (1992), for instance, the existence of a black majority in South Africa makes possible a concessional or even liberal democracy (as now seems to be the case), whereas Israel's insistence on remaining a Jewish state means that the only viable solution is a separate state for the Palestinians.

Despite its broad appeal, the ethnic approach is problematic. Ethnicity itself is of course highly important, but to make it a basis for analysis is to put history on its head. As it stands, the approach is essentially descriptive. Its basic proposition is that one ethnic group discriminates against another in the allocation of resources, and that on a world scale this discrimination moves in an endless "cycle of cultures," or a "clash of civilizations," in the words of Huntington (1993). Everything else-from technical change, through private property, to wage labor, to modernity, to the state, business enterprise, the stock market, or globalization - is merely a "stimulus" or "input" into the fundamental social condition of ethnic conflict. This, however, leaves a whole set of questions hanging in the air. How do such nonethnic processes come into being in the first place? What are their interconnections? And most importantly, are they not important in their own right? In our view, the challenge is not to explain ethnic conflict per se, but to offer a framework in which ethnicity can be understood within the broader context of capital accumulation, class politics, international relations, and the state.

A second group of studies looked more closely on aspects of political economy in the two countries. The most thorough comparative work is by Greenberg (1980), who contrasted the historical experience of South Africa, Alabama, Northern Ireland, and Israel by analyzing the relationship between capitalist development, ethnic conflict, and national institutions. The principal weakness of Greenberg's book, echoed elsewhere in the literature, is an overemphasis on labor. This focus, while revealing for precapitalist colonialism, seems too limited a basis for unraveling the complexities of mature capitalism like that of South Africa and Israel in the postwar era.

Since the late 1970s, Israeli writers began paying closer attention to the political economy of Zionism, particularly its colonial aspects. According to Farjoun (1978, 1980), Rosenfeld (1979), and Gozansky (1986), Zionism tried to impose "unequal development" on the Palestinians from the very beginning, a process which eventually manifested itself in "internal colonialism," based on ethnic segmentation between Jews and Arabs in the labor 
market. With the growing popularity of post-Zionism in the late 1980s, this view has been further generalized to suggest that the entire development of the Jewish economy could be attributed to the demise of its Palestinian counterpart (Shafir, 1989). Some, like Kimmerling (1983), argued that the socialism of the early years was more instrumental than ideological-it was necessary for the initial phase of colonization, but redundant thereafter. And, indeed, after 1967, socialism was dropped in favor of unfettered ethnic colonization, as practiced by both Labor and Likud governments.

In South Africa, a somewhat similar dispute centered on the role of apartheid, with the main contention running between liberals and Marxists. Liberals such as Lipton (1985) argued that apartheid, with its ethnic exploitation of black labor, was adequate for the earlier stage of "primitive accumulation." With growing capital intensity and the integration of the Afrikaners into urban society, however, apartheid had become a burden and should slowly wane. A contrary view was offered by neo-Marxists such as Johnstone (1970) and Legassick (1974). Based on dependency theory, they argued that by regulating the flow of cheap black labor, apartheid was in fact beneficial for accumulation in a peripheral country like South Africa. This claim was later supported by "structuralist" writers, who, in the spirit of Poulantzas (1975), sought to examine capitalist development in the broader context of political, electoral, and bureaucratic realignment. Davies, Kaplan, Morris, and O'Meara (1976), for instance, argued that the rise of apartheid was largely a reflection of the inner conflict between international and South African capital, with the latter striving to alter its semiperipheral position. Since 1924, the principal vehicle for this transformation was the increasingly politicized nature of exploitation. The result was an intensified class struggle, in which the expanding state apparatus, particularly after the 1948 rise to power of the National Party, served to unify capital in a common front against labor. Another strand in the Marxist literature, following the social structure of accumulation (SSA) and regulation schools, suggested that apartheid operated as a "racial Fordist regulation" (Gelb, 1987) or "peripheral Fordism" (Ramos \& Cassim, 1989, cited in Nattrass, 1992). According to this latter view, apartheid helped resolve the structural crisis of the 1940s, but since the 1970s began crumbling under a realization crisis, with limited mass consumption unable to offset rising capital intensity.

The main weakness of this political economy literature lies in its treatment of accumulation. The first problem, pointed out by Nattrass $(1989,1992)$, is that the theoretical discourse on accumulation is often supported by little or no evidence. For instance, according to her own empirical findings (and contrary to the unsubstantiated regulation/SSA thesis), during the apartheid period the rate of profit in fact trended down, not up. Furthermore, the principal reason for this downtrend was a rising income share of labor-exactly the opposite of what apartheid was supposed to deliver. As we argue later in the article, Nattrass's own evidence and conclusions are questionable, but her insistence on facts is warranted.

The second problem is the global context. Although the semiperiphery nature of the two countries is repeatedly mentioned, this is yet to be integrated into a coherent framework of accumulation. Indeed, when it comes to empirical analysis, the issue is either glossed over or ignored altogether. This is a critical omission. In our view, the global position of the two countries is fundamental for understanding both their historical development and current transition. 


\section{The great U-turn: why now?}

In reassessing this transition, it is convenient to start from the end: what triggered the U-turn in the two countries, and why did it happen in the late 1980s? The commonsense answer is that both transitions were set off by crisis, though the periodization of the process is not simple. Consider first the role of political crisis. According to the ethnic school, the causes of the conflict are neither new nor have they been altered. In South Africa, these roots date back to the symbolic almond hedge planted in the mid-seventeenth century by Van Riebeek in order to separate the Dutch colonists from the local Khoikhoi. In Israel, the conflict began in the 1920 s with the first significant Jewish immigration into Palestine. This raises three questions. First, if the ethnic/racial parameters of the two conflicts have not fundamentally changed, why was the shift toward reconciliation so sudden, taking most people_including opposition activists-by surprise? A second, related, problem is that although both countries have experienced mass revolt (the 1980s black uprising in South Africa and the Intifada in the occupied Palestinian territories), in neither case did the revolt succeed in bringing the prevailing racist/colonial regime down to its knees. Both crises were significant, but their severity was hardly exceptional by historical standards. South Africa withstood previous uprisings and international isolation, whereas a heavy war effort of close to half a century has done little to change Israel's attitude toward regional integration. Indeed, and this leads us to the third point, one may argue that there was in fact no political crisis. Note that the current transition in both cases has been relatively peaceful. Contrary to dire prediction, South Africa's transformation into a constitutional democracy occurred without an all-out civil war, whereas in Israel, despite considerable opposition, significant counterforces and repeated setbacks, the Middle East peace process has not disintegrated into renewed mass violence or war.

An alternative explanation is that the U-turns in the two countries were triggered by serious economic crises. Yet this thesis too, at least in its undiluted form, is unconvincing. Fig. 1 displays two indicators for overall economic activity in each country; the first measures the annual rate of growth of GDP and the second expresses the level of GDP relative to world GDP (in both cases original series are in constant prices). According to the chart, the South African crisis started as early as the mid-1960s, with the economy entering a protracted downtrend (relative to its own history, as well as the world as a whole). Obviously, no elite can remain impartial to an ever-intensifying calamity, so, on the face of it, South Africa's eventual transition should seem hardly surprising. The problem with such explanation is that until the late 1980s, worsening political-economic conditions seemed to have strengthened the elite's resolve. And if that is so, why the sudden reversal in the 1990s? Was the 1985-1986 imposition of emergency rule simply a psychological reaction to siege, and its removal a sign of fatigue and surrender, or was there something underneath the aggregate figures which made the crisis easier to withstand initially, but unbearable later?

The impact of economic crisis on the Israeli transition is even more complicated. Israel's economic turbulence started in the 1970s, with growth dropping sharply from its earlier highs. The plunge, however, came in the context of global weakening; and although falling, Israeli growth continued to outperform the world's average (albeit more moderately). Until the late 1980s, the economic crisis was seen as partly rooted in the global malaise, and 


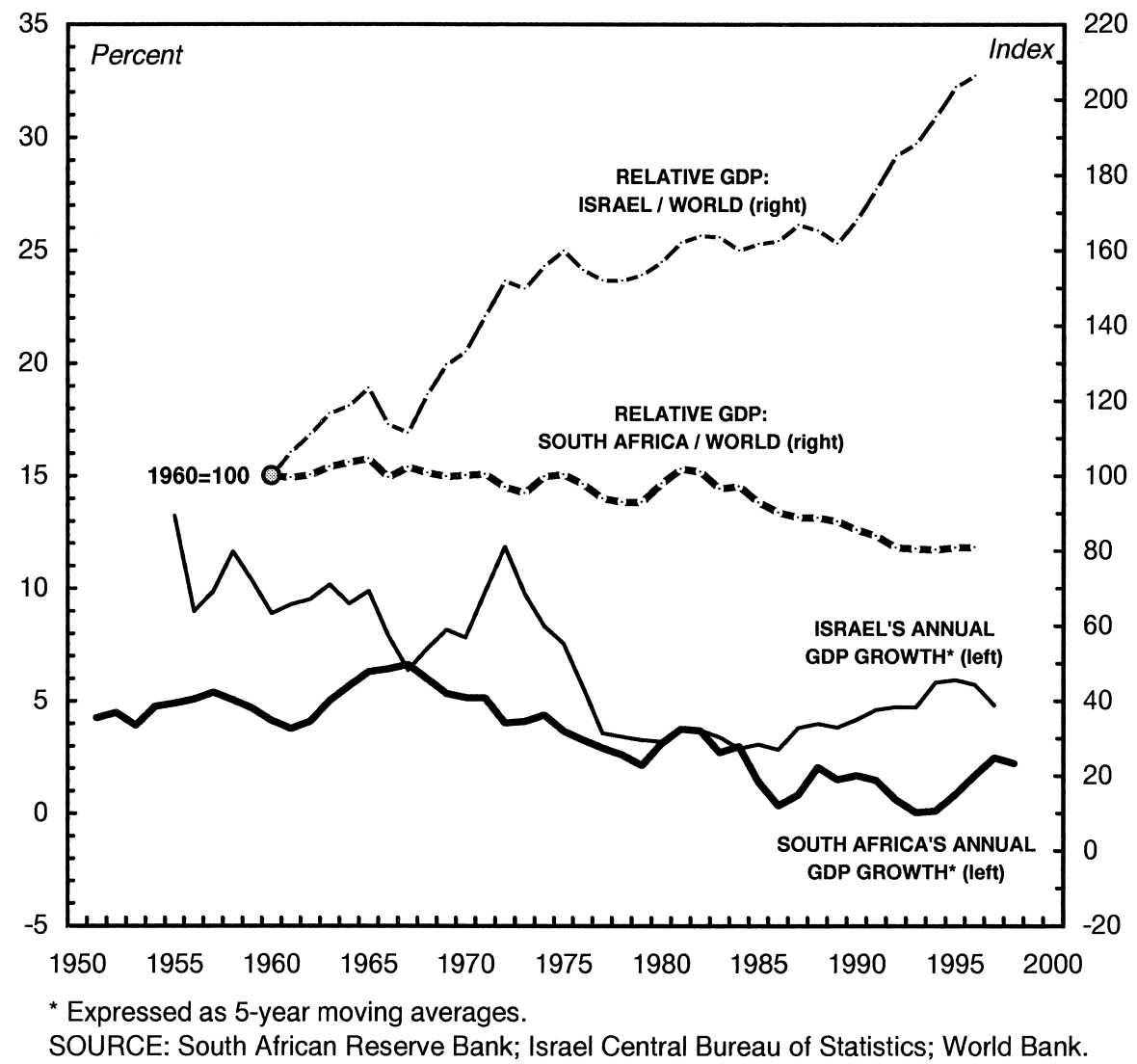

Fig. 1. Real GDP.

largely unrelated to Israeli-Arab conflict. Indeed, the economic reacceleration in the 1990s, although coinciding with the beginning of regional reconciliation, was largely due to an influx of immigrants from the Commonwealth of Independent States. Unlike in South Africa, therefore, Israel's transition could not be easily attributed to economic attrition.

In our view, these apparent inconsistencies arise largely because we are looking in the wrong direction. Although the U-turn in both countries unfolded in the midst of general turmoil, the process can be significantly sharpened by looking underneath the aggregates. First, note that in both cases the transition has been nonrevolutionary. Despite the class nature and racial overtones of the two conflicts, their attempted resolution proceeds within the framework of a capitalist world order. The focus therefore should be not on the overall indicators per se, but on the way they affect accumulation. Second, in both cases change has been conceived and carried out at the top. It is a pact among the elites, not the demise of these elites. The implication is that our discussion of accumulation itself has to be disaggregated, focusing on differential performance and relative power.

This latter emphasis serves to dispel the myth of "aggregate loss" driven by persistent "policy errors" and grand "mistakes." In a context of power conflict, the proper indicators for loss and gain are relative, not absolute. As we argue below, this is true not only in the 
so-called political domain, but also in the realm of business enterprise and accumulation. As suggested by Olson $(1965,1982)$, although in somewhat different terms, and as documented endlessly throughout history, the loss of many often conceals huge gains for the few.

From this perspective it is also misleading to blame elites for their "short-sightedness." Every elite could be (and often is) wrong in assessing its own long-term interests. But it is hardly convincing to propose that elites, particularly capitalist, could be persistently blind to their short-term interests. The tension between these two time perspectives, difficult as it may be to define and measure, is a crucial historical force. When long-term considerations coincide with short-term conditions, the course seems obvious. But when the two pull in opposite directions, it is the short term which often proves paramount. In this sense, the racist regime in South Africa, as well as the colonial regime in Israel, were not "mistakes," much like imperialism was not a capitalist error as Schumpeter (1955) tried to show, and Vietnam was not an American blunder as Tuchman (1984) proposed (on the "mistake theory" of history, see Barnet, 1972). Instead, we suggest that, for the elites of both South Africa and Israel, the short-term differential benefit from sticking to their guns despite the aggregate crisis was large enough to put off for later the need to deal with long-term concerns.

\section{Differential accumulation}

The basic hypothesis in this paper is that the great U-turn in the two countries has been part of a broader transition in the nature of global accumulation. Our theoretical framework is based on a revised notion of capital and an associated theory of accumulation. This framework, developed more fully elsewhere, is briefly outlined in this section. ${ }^{1}$

\subsection{Capital accumulation: production or power?}

As it stands, capital theory is besieged by serious methodological problems. The principal difficulty derives from trying to reconcile the social and material aspects of capital, or its essence as "power" and "wealth." The neoclassicists resolved the problem by eliminating it in the first place; for them, capital is only material wealth. As documented endlessly from J.B. Clark (1899), through Marshall (1920: 648-49), to Schumpeter (1954: 632-63), to modern textbooks, the basic neoclassical assumption is that the value of capital derives from the productivity of the underlying capital goods. Even Böhm-Bawerk (1923), who tried to treat capital as a temporal technological process, remained caught in the boundaries of production. For mainstream economists, the power aspect of capital, if that is ever an issue, is an "imperfection," a social dimension external to its existence as tangible wealth. This materialistic view of capital was challenged early on by Veblen (cf. 1904, 1908a, 1908b, 1923) and later exposed as a logical impossibility by the Cambridge Controversy (Harcourt, 1972; Howard \& King, 1992: part IV). Capital, the critiques showed, cannot be measured independently of prices and distribution, and therefore cannot be thought of as a distinct physical entity in the first place.

Contrary to the neoclassicists, Marxists do not see capital as a thing, but as a comprehensive process of social reification (for instance, Wright, 1977: 198; Shaikh, 1990: 73). For 
Marx, accumulation had two basic dimensions: a qualitative dimension involving the very commodification of social relations, and a quantitative dimension consisting of the progressive augmentation of capital measured in monetary terms. The problem was how to link the two. Marx's choice was to concentrate on production, particularly the labor process, whose commodification he considered the main manifestation of capitalist power, and whose quantification as "dead labor" was therefore to be the underlying unit of accumulation. This, though, was easier said than done. In order to provide the "quantitative code" of accumulation, the labor process itself must be objective, quantifiable, and observable. Yet, as Marx himself anticipated and as the Cambridge Controversy was to later demonstrate, once we go beyond the most simple production processes these requirements no longer hold (Steedman, 1975, 1977; Tsuru, 1993: Ch. 1). Indeed, the very tendency of capitalistic production to become ever more complex makes it practically impossible to identify the distinct "contributions" to value of specific labor inputs. But if we cannot identify these contributions, even on paper, how can we measure the "labor contents" of capital?

As we see it, the solution is to redefine accumulation, not as an offshoot of production, but as a broader tension between productivity and power.

Perhaps the first attempt to develop an institutionalist theory of capital along these lines was offered at the turn of the century by Veblen. Criticizing the prevailing consensus of his time, Veblen pointed out that, unlike economists, businessmen tended to think about capital and accumulation in pecuniary, not material terms. For the modern investor-the owner of corporate stocks and bonds-capital does not denote machines, structures, or raw materials, and accumulation has little to do with the material augmentation of such articles. Instead, capital simply means the monetary value of the owned securities, and accumulation is nothing more than the temporal increase in that value. The value of capital is of course not an independent entity. It is a capitalization of anticipated business earnings, and its pace of accumulation depends on the expected growth of such earnings. Contrary to prevailing convention, however, Veblen argued that the source of these earnings was only partly and often not at all related to the underlying productivity of the owned machines as the neoclassicists claimed, or of the hired workers as the Marxists maintained.

What severed the conventional link between profits and productivity? The principal cause, according to Veblen, was the growing separation between "industry" and "business," or between productive activity and absentee ownership. Production is essentially an integrated communal process, which means that its output depends mostly on the complex interaction of its numerous social components, and only marginally if at all on their individual contributions. The implication is that distribution in general and the income of capitalists in particular are largely manifestations of power.

Note that unlike the neo-Ricardians after him, Veblen never suggested that distribution was somehow independent of production. On the contrary, the two were intimately connected; only their relationship was complex and potentially nonlinear. Production was of course necessary for profit, but "too much" of it could be just as hazardous as "too little." From a Veblenian perspective, the ultimate source of capitalist power rests with strategic business "sabotage," or the ability of absentee owners to limit societal production below its full potential. Under certain circumstances, the limitation remains latent. For instance, when rapid population growth far exceeds the pace of technical change, high profits could be 
earned merely through the threat of unemployment. Capitalism, however, tends to come with accelerated technical change, and hence the specter of excess capacity, and that can be offset only through active "sabotage." Under these latter circumstances, a certain degree of stagnation is not a menace, but a prerequisite for profit.

The rise of "big business" and "big government" during the later part of the nineteenth century extended the power institutions of "sabotage" well beyond the seemingly automatic boom/bust mechanism emphasized by Marx. In the present century, these institutions shifted further into the political realm of the state, with factors like policing, propaganda, taxation, tariffs, subsidies, patent laws, and intellectual property rights now being increasingly augmented by international institutions such as trade zones, regional investment agreements, and global, government-backed corporate alliances.

Power, however, is not only the means of accumulation, but also its most fundamental aim. In this sense, large-scale business enterprise is driven by the same principal force which animated all previous power civilizations: namely, the quest to control nature and people (Mumford, 1967, 1970). This emphasis serves to explain why, when we come to the measurement of power, standard economic indices such as "production," "employment," "sales," or "prices" are not very useful. These categories are typically conceived from the viewpoint of hedonic utilitarianism popular during the earlier stage of competitive capitalism; their ultimate purpose is to tell us something about well-being. From the power perspective of mature capitalism, however, such indices are rarely illuminating since the quest for domination and control has little to do with utility and well-being (at least not in the neoclassical sense). And indeed, the typical large firm displays no intrinsic interest in producing more rather than less, or in making its product cheap rather than expensive. These issues are of course highly significant, but rarely as ends in themselves; instead, they are merely the means by which the corporation seeks to achieve a higher goal: that of earning profits.

The primacy of the profit motive is of course well-known, but its interpretation remains problematic. The difficulty arises when mainstream economic theory proceeds to assumemistakenly in our view - that the quest for profit could also be denominated in utilitarian, hedonic terms (note the common practice of deflating profit by a price index as a way of deriving its "real" magnitude). The notion that the global business behavior of Exxon, Mitsubishi, Daimler-Chrysler, Anglo American, or Koor is ultimately geared toward maximizing their owners' ability to consume simply sounds irrelevant. Large-scale business enterprise is of course obsessed with profitability, though the reasons have little to do with hedonic considerations.

\subsection{To maximize profit or beat the average?}

In our view, the ultimate goal of investment, particularly in the context of big business, is not tangible, but nominal gain. ${ }^{2}$ This latter emphasis is rooted in the differential essence of business enterprise. Regardless of rigidities, collusion, and collaboration in the organization of production or sales, the ownership of capital is forever a competitive, antagonistic endeavor. For the large firm, success or failure is measured not in terms of increase or decrease in the quantity of commodities their profit can buy, but rather in relation to what 
other firms have achieved: a 20\% drop in profit during recession is far less disconcerting that a $10 \%$ rise when other firms achieve twice that much. Indeed, contrary to customary textbook notions, modern corporations appear preoccupied not with "maximizing" their profit, but with "beating the average."

The emphasis on differential as opposed to maximum profit is important for several related reasons which are summarized here in point form.

1. Differential accumulation inverts the accepted relationship between distribution and accumulation. The conventional view in political economy is that redistribution is a vehicle of accumulation. The power essence of differential accumulation, on the other hand, suggests that redistribution is the very goal of accumulation. Profit is sought not for consumption, but as evidence of power whose meaning is always relative.

2. Emphasizing the differential drive highlights the "subversive" as well as more straightforward aspects of accumulation. Whereas profit maximizers seek to boost their own gain, differential accumulators are equally interested in undermining their rivals: such "sabotage," quite apart from its impact on their own profitability, helps improve their relative performance.

3. The differential nature of business suggests a broader framework for analyzing the links between production, business limitations, and profit. In this framework, the distribution of profit depends on the differential damage capitalists inflict on one another; the aggregate effect of this struggle is to limit societal production below its full potential; and this overall "sabotage" determines the aggregate profit share (through a nonlinear relationship which is initially positive and subsequently negative).

4. The focus on differential performance enables us to incorporate, from the very beginning, broad aspects of power into the basic concept of capital. Although Marx was probably interested in doing just that, his insistence on rooting the "gist" of accumulation in the productive labor process paradoxically brought other facets of power which he emphasized, such as the centralization of capital or the emergence of big government, into potential conflict with his underlying labor theory of value (for instance, by violating competition, or by obstructing the free movement of labor and capital).

5. Whereas the study of profit maximization can be illuminated by a disaggregate approach, differential accumulation requires such an approach. If accumulation in general depends on the power institutions at the center, studying the broad contours of capitalist development must be anchored in the interaction of core firms, key state organs, and international organizations which shape this development in the first place.

6. Unlike the mythical "maximum profit" which is forever unobservable (and sometimes even undefined, as in the case of competitive oligopoly), differential accumulation is real, measurable, and appears to be everywhere. References to the "average" or "normal" pervade the business media-from the analysis of stock performance, through the stacking of country growth rates and risk premia, to the ranking of corporate profitability and of the world's richest people. This differential habit of thinking, more than anything else, animates the owners and managers of both large corporations and state organs. 
Summing up, the relative essence of power suggests that accumulation can be best understood in reference to the differential experience of the dominant or "core" group of capitalists in a given society. The main task is to explain the historical evolution of this core in light of its internal and external struggles, its conflict with labor, its relationship with the state, and its role within the global process of differential accumulation.

\subsection{Commodified power and dominant capital}

How should differential accumulation be operationalized? What exactly is being accumulated and how could it be quantified? In our view, the value of capital represents neither material wealth, nor a productive amalgamate of "dead labor," but rather commodified power. Capitalists accumulate not things carried over from the past, but power titles projected onto the future. Their claim is not for a share of the output, but for a share in the process of producing such output. Finally, their principal power leverage is not the ownership of capital goods or means of production per se, but their broader ability to control, shape, and influence organizations and institutions.

This power essence of accumulation is often obscured by the traditional distinction between profit and capital. Both Marxists and neoclassicists see accumulation as "backward looking" with respect to profit: the augmentation of capital is a consequence of profit, and hence takes place after the profit is earned. Furthermore, both schools view profit and accumulation as related through distinct categories. Although profit is an addition to capital, the latter stands on its own, as an amalgamate of past investment or labor time. ${ }^{3}$ This view stands in sharp contrast to a Veblenian (or business) perspective which sees capital as finance, and only finance. As such, capital is merely the present value of expected earnings, so its accumulation is entirely "forward looking," occurring before, not after, the profit is earned.

From a forward-looking perspective, capital appears not as an independent stock, but as a "crystallized flow," the present value of a future earning stream. Over the long haul, with profit expectations oscillating around their actual values, the pace of accumulation and the rate of growth of profit tend to converge, allowing us to treat them interchangeably. In this context, the relationship between past and current labor should be interpreted qualitatively rather than quantitatively. Instead of viewing dead labor as fixed capital and living labor as variable capital, we can see the former as representing existing power institutions, and the latter as attempts to alter such institutions. Clearly, this qualitative relationship is far too loose as a basis for historical "laws of motion" such as the falling rate of profit. Nonetheless, it enables us to understand the quantitative aspects of accumulation and the qualitative institutions on which it is based as two sides of the same power process.

Although capitalists exert their power over society as a whole, they measure it relatively to other owners, so accumulation should be expressed differentially. This can be briefly summarized in three related propositions.

1. From a static perspective, the "differential power of capital" possessed by a group of owners is given by comparing their profit (or capital value) to that of the average 
capital unit. For instance, if the average annual profit is $\$ 5$ million, the differential power of a group with annual profit of $\$ 1$ billion is 200 .

2. From a dynamic viewpoint, the pace of "differential accumulation" is given by the rate of change of the "differential power of capital." Positive, zero, or negative rates of differential accumulation imply rising, unchanging, or falling differential power, respectively.

3. From a power dimension, only capitalists with a positive rate of differential accumulation are said to accumulate.

The core group of "dominant capital" comprises the largest differential accumulators. The basic criterion in identifying this group should be teleological, based on the profit ranking observed at the end of the process. The "survivorship bias" implicit in this procedure means that core members will be those which have previously enjoyed the fastest rate of differential accumulation (measured over a sufficiently long period). This is adequate for our purpose, since our goal is not to show that these firms have grown powerful (which is obvious), but rather to examine the relationship between their ascent on the one hand, and broader societal developments on the other.

In practice, the boundary of dominant capital is arbitrary to some extent (as it is with all concentration indices). Most generally, the choice of a cutoff point needs to satisfy two general criteria. First, core companies have to enjoy considerable market power and political leverage. Second, the group as a whole should not be too broadly defined. Indeed, once a few corporations grow "too big" relative to their own benchmark, "beating the average" becomes not only impossible, but meaningless. When that happens, differential accumulation can proceed only relative to a wider universe, prompting core firms to transcend their existing universe. The particular choice of universe is therefore historical, depending both on the stage of corporate diversification and the ease of capital movement. Over time, this choice is likely to expand from specific sectors, to the whole country, to a group of countries, and eventually to the world as a whole. Of course, any change of universe requires also a redefinition of the core itself.

\subsection{Regimes of differential accumulation}

The historical trajectory of differential accumulation is determined by both technical and social considerations (Nitzan, 2001). The technical limits derive from the bounded nature of redistribution: in principal, a group of capitalists can always raise its profit, but it can never, even on paper, control more than $100 \%$ of all profit. This means that the greater the differential power of dominant capital and the faster its differential accumulation, the more difficult they become to augment further in the future. Under these conditions, differential accumulation can continue only by taking over new production. However, as long as the core is still not too big, these limits are not imposing. Differential performance can then de-couple from broader aggregates, and even benefit from stagnation or a drop in overall profit (which make the average easier to beat). In these circumstances, the actual path of differential accumulation is determined by a complex set of social, political, and economic considerations to which we now turn. 
In principle, profit growth could be thought of as a product of two components: the rate of growth of sales and the rate of growth of the profit share in sales (ignoring second-order components). For the dominant capital core, a positive rate of differential accumulation could hence be achieved by following two distinct routes: either through the "breadth of accumulation" by expanding sales faster than the average to increase market share, or via the "depth of accumulation" by raising the profit share of sales faster than the average. ${ }^{4}$ Each of these avenues is further subdivided into "internal" and "external" subroutes, so we end up with a four-way classification:

1. Breadth/Internal. Differential expansion in the breadth of accumulation could occur internally through the redistribution of existing demand. The principal method is mergers and acquisitions, in which the core group is using amalgamation as a means of expanding its control over sales and, by extension, over the stream of profit. Since corporate amalgamation does not in itself alter the overall level of sales, the net result is the expansion of market share in favor of the acquiring groups. This is a potent avenue of differential accumulation; it is however inherently limited by the overall level of economic activity available for redistribution, and by societal and technological barriers on corporate concentration.

2. Breadth/External. This method involves the redistribution of new demand, principally generated by population growth and by proletarianization. Following this route, the core group expands its market share by incorporating new production faster than other owners. Because other groups also enjoy the general expansion of demand, the short-term impact on differential accumulation is usually less dramatic than that of mergers and acquisitions. However, it is also far more sustainable, particularly as long as significant portions of the population are yet to be proletarianized.

3. Depth/Internal. The purpose is to increase profit margins faster than the average, and one way of achieving this is by superior cost cutting. This can be done by improving efficiency and/or by reducing input prices. Although the core groups are routinely forced to obey these imperatives, the usual consequence is more to meet than to beat the average. The reason is twofold: first, production technology is difficult to monopolize indefinitely, and, second, even the most powerful corporate coalitions have only limited control over input prices.

4. Depth/External. The purpose is still to deepen profit margins faster than the average, but here the vehicle is price, not cost. For any single seller, higher prices are usually more than offset by lost volume; the same is not true for a coalition of sellers, however. Acting in concert, a group of sellers could well benefit from higher monopoly margins because, up to a point, the relative profit gain per unit outweighs the relative decline in volume.

For our purpose here, it is important to distinguish between differential accumulation of a particular corporation and differential accumulation as a broad social "regime." A single core firm can often advance through both breadth and depth. That is not the case, though, for the core as a whole. The reason is that as overall regimes, conditions which are conducive to breadth often undermine depth, and vice versa. The main incompatibility runs between their external avenues. 
Periods of rapid population growth and proletarianization tend to loosen the internal cohesiveness of corporate coalitions, making differential price increases both more difficult and less desirable (since they undermine market share). The situation changes markedly when population growth subsides or when proletarianization runs into barriers. When that happens, pricing power, as well as the benefit from deeper margins, tend to rise. The key factor is the effect on collective action of a stagnant economy. With demand growth stalling, further expansions in market share are not only difficult, but also raise the risk of an uncontrolled price war. The primary alternative is inflationary increases in profit margins, which, when fed through the "normal rate of return," eventually spread into a generalized inflationary spiral. The ultimate differential outcome, however, is usually beneficial for the core, and as long as this remains the case, its pro-inflation consensus remains intact. Moreover, because inflation in this context is driven not by production bottlenecks but by institutional barriers, it ends up as stagflation, aggravating rather than alleviating the production lull.

The breadth/depth framework leads to two tentative hypotheses and a set of related questions. First, it suggests that under mature capitalism, with differential accumulation becoming increasingly important, the long-term relationship between inflation and growth is negative-quite the opposite of received convention. The belief that inflation and growth are positively related - whether valid or not-is usually based on a cyclical argument of supply constraints, and is hence meaningful only in the short term. Over the longer haul, though, material bottlenecks are irrelevant. The key issue is institutional limitations, which in our framework revolve around the "incompatibility" of breadth and depth. From a historical perspective, shifts from one regime to the other should cause the macroeconomy to oscillate between the extremes of growth with low inflation on the one hand, and stagflation on the other. Surprising as it may sound, this is exactly what happened in the industrialized countries over the past half century. ${ }^{5}$

The second hypothesis concerns the nature of social conflict in the two regimes. Generally speaking, external breadth thrives on the conquest of new profit streams, and is therefore likely to be associated with a restructuring of power institutions. Depth, on the other hand, is based on deepening existing distributional patterns, and hence on the consolidation of power arrangements. The difference between "new" and "existing" profit streams, as well as between institutional "change" and "consolidation," is not always obvious, of course. But given that depth is commonly characterized by a zero-sum struggle, whereas in breadth the battle lines are often blurred by overall growth and expansion, we can expect the former to be more conflict-ridden than the latter, if only in appearance.

The interesting questions revolve around the "choice" of regime. What structural forces and conscious action favor one regime over another? Why and how does a regime run its course? What triggers a transition from one regime to another? These questions can be addressed at three levels. Most generally, the centrifugal forces of capitalism-particularly the effect on competition of technological change and the perpetual enticement to venture into noncapitalist areas-make breadth the path of least resistance. An inflationary depth regime, on the other hand, is intensely antagonistic, unstable, difficult to manage, and often uncertain in outcome, but it also has huge differential potential (shown most vividly during hyperinflation). Thus, when competition starts to seriously undermine profit margins, and/or 
when proletarianization runs into barriers, the core groups gravitate, with a mixture of fear and greed, toward depth.

At a more detailed level, the relationship between the different regimes is determined by technical ceilings, as mentioned earlier. For instance, the scope of internal breadth is constrained by both the prevailing level of corporate concentration and the pace of external breadth; external depth by the relative size of the rural population, or by the inflow of immigration; and internal depth by productivity changes. External depth, on the other hand, has no technical limit, and can intensify as long as inflation continues to accelerate. The main determinants here are societal, for instance the extent of social instability, or the existence of smoothing institutions such as indexation.

Such socio-institutional considerations are crucial at the concrete, historical level of analysis. For example, having a large rural population does not guarantee proletarianization, which can stall for cultural or religious reasons; legal restrictions can nip an amalgamation drive in the bud; or tight cooperation among elites may enable inflation despite the attendant instability. These circumstances are often domestic in nature, although sometimes, as in the case of South Africa and Israel, external conditions could play an equal or even more important role.

\section{Differential accumulation in South Africa and Israel}

Both South Africa and Israel have seen the emergence of large, dominant capital groups. In South Africa, this group included by the late 1980s Anglo American, De Beers, Sanlem, South Africa Mutual, Rembrandt, Anglovaal, and Liberty Life, as well as several lesser companies (Innes, 1984; Fine \& Rustomjee, 1996). Many of these corporations have their roots in the early diamond and gold discoveries during the latter part of the nineteenth century. Since then, they have diversified, amassed considerable political leverage, developed close ties with one another, and together came to account for a lion's share of South Africa's profits. Analyzing their differential performance, however, is made difficult by an intricate structure of cross-ownership (Innes, 1984; Gardiner \& Rösgen, 1996). Consequently, we use Anglo American Corporation (AAC) alone as a proxy for South Africa's dominant capital. The choice is admittedly imperfect, but not altogether inappropriate given AAC's disproportionate political and business clout (various estimates put its combined market reach, including chained subsidiaries, in excess of half the market capitalization of the Johannesburg Stock Exchange).

In Israel, our dominant capital proxy consists of five principal holding groups (denoted here as HG), which in the late 1980s included Bank Leumi, Bank Hapoalim, Discount Bankholding, Koor, and Clal. These firms have their roots in the preindependence period (with the exception of Clal), and, like in South Africa, enjoy intimate ties with the state as well as with one another (Aharoni, 1976; Rowley, Bichler, \& Nitzan, 1988; Bichler, 1991). Recently, the core has expanded to include several rapidly growing companies such as Bezek, Teva, Israel Chemicals, Israel Corporation, and Elco Holdings, as well as subsidiaries of transnational corporations, but given their relatively late arrival, they are excluded from our study (see Section 8). 


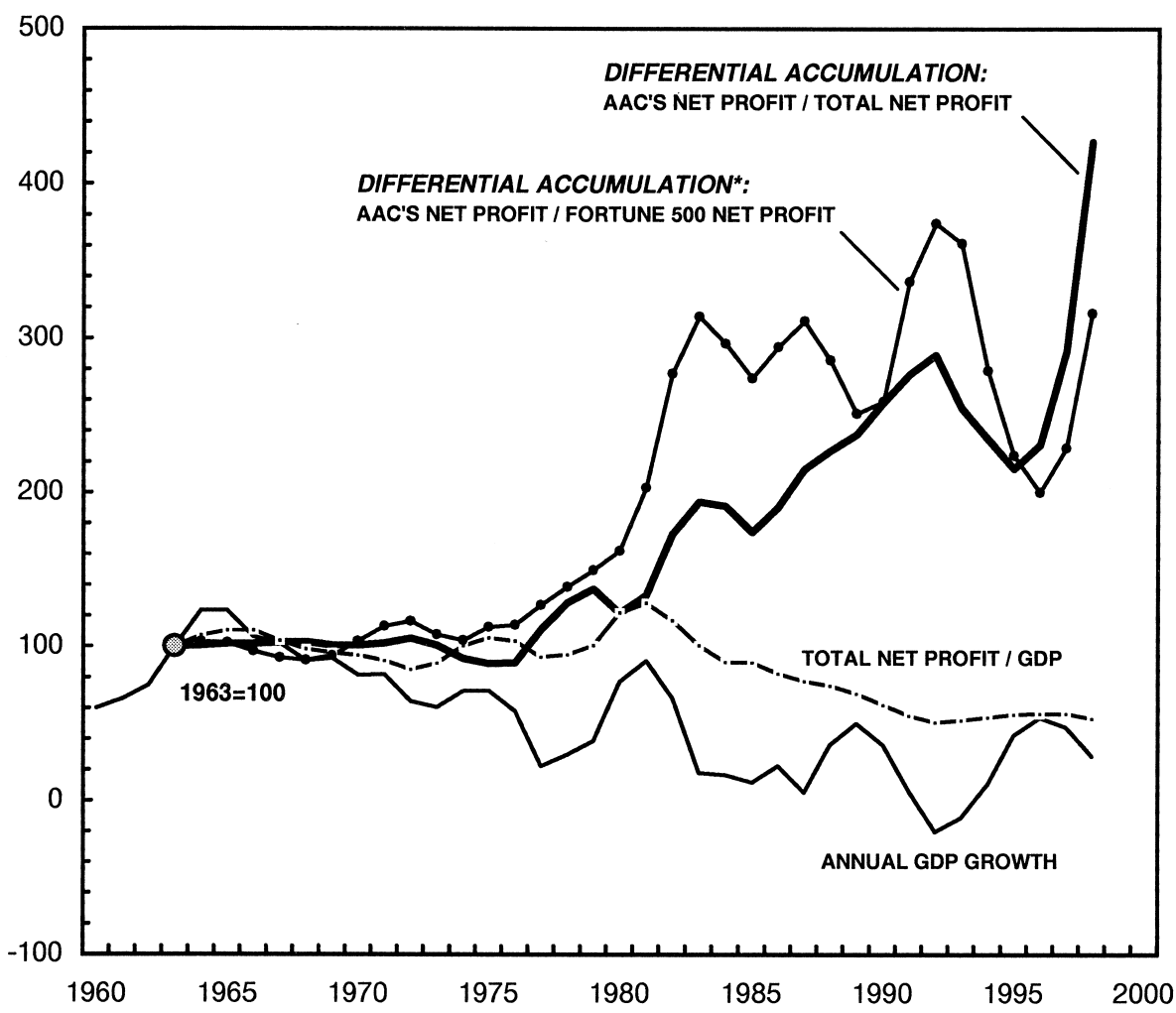

NOTES: Original series are expressed as 3-year moving averages. AAC's data for 19961998 are preliminary. Fortune 500 data after 1993 are re-based to reflect a shift in the list from industrial to all corporations.

* Original data are expressed in constant local prices.

SOURCE: South African Reserve Bank; Anglo American Corporation; Fortune.

Fig. 2. South Africa.

Using AAC and HG as our operational indicators for dominant capital in the two countries, our analysis in this section contrasts their relative performance with broader aggregates. In the case of South Africa, depicted in Fig. 2, we compare (1) the aggregate performance of the economy measured by GDP growth, (2) the distribution of income measured by the net profit share of GDP, and (3) the process of differential accumulation indicated by changes in the "differential power of capital." This latter indicator is measured twice: by the ratio between AAC's net profit and total net profit, as well as by the ratio between AAC's net profit and the net profit of the Fortune 500 companies in the United States (the latter index, while less relevant for the earlier years, is important for the current globalization stage discussed in Section 8). All series are smoothed and rebased for comparison.

Contrasting these indices reveals the staggered nature of the apartheid crisis. Overall growth began to drop as early as the mid-1960s; the profit crisis started more than fifteen years later in the early 1980s; whereas the differential accumulation crisis began sometime 


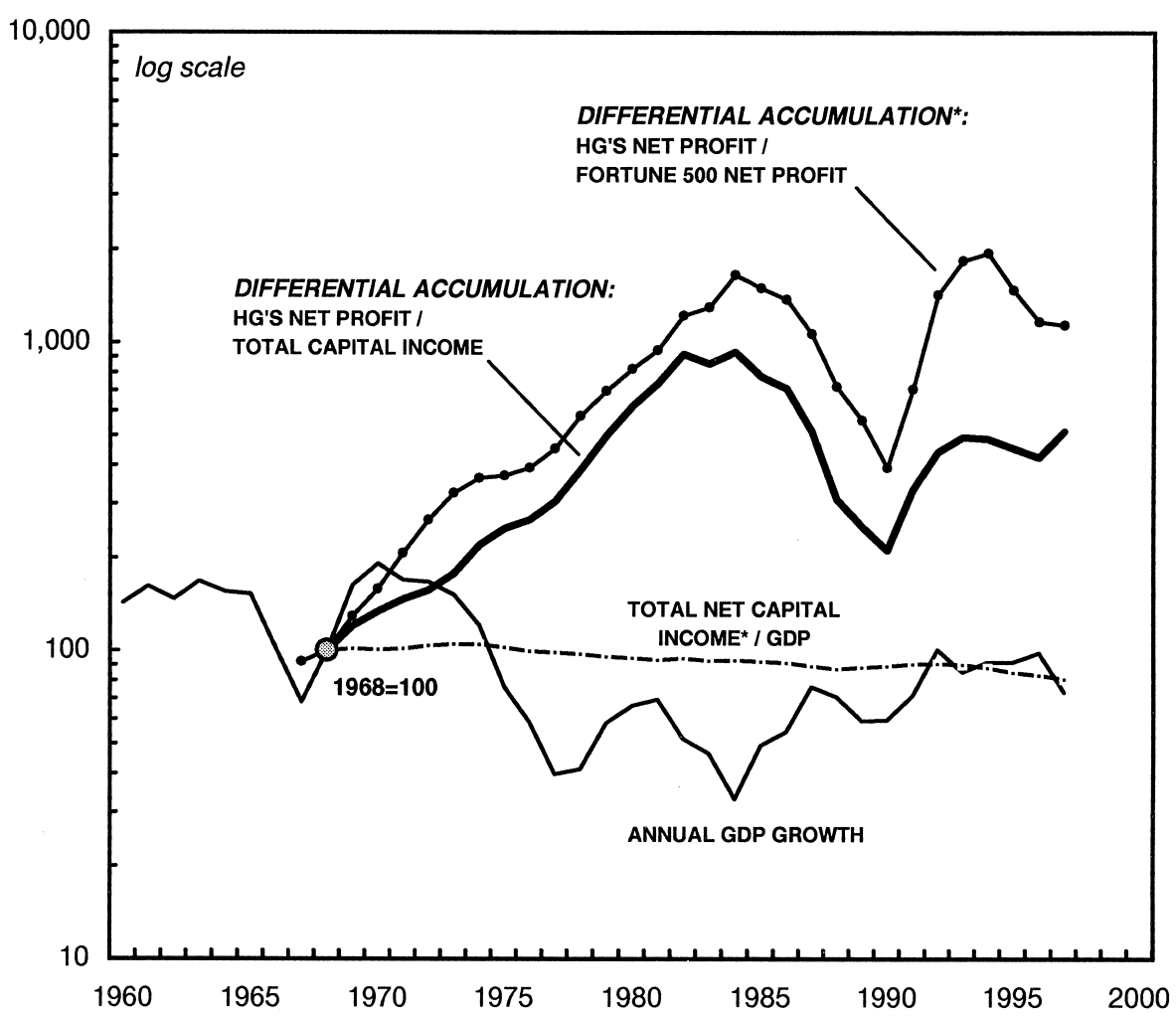

NOTES: Original series are expressed as 3-year moving averages. Net capital income is computed by subtracting from net national income the wage bill and direct taxes paid by corporations and unincorporated businesses. HG data for 1996-1997 are preliminary. Fortune 500 data after 1993 are re-based to reflect a shift in the list from industrial to all corporations.

* Original data expressed in constant local prices.

SOURCE: Israel Central Bureau of Statistics; corporate financial statements; Fortune.

Fig. 3. Israel.

between the late 1980s and early 1990s, depending on the measure. Indeed, until the mid-1980s, differential accumulation seems to have accelerated despite the broader turmoil (or perhaps because of it). In other words, only by the early 1990s were all indicators pointing down. Moreover, recently the indices have again diverged; while the economy relapsed into recession and profit growth remains morbid, differential accumulation rebounded sharply.

The Israeli experience, depicted by comparable indices in Fig. 3, also shows a marked divergence. (The chart uses imputed total capital income rather than profit, which are not published in Israel.) The period between the early 1970s and mid-1980s was marked by a general crisis, with sharp declines in overall growth and in the growth of capital income (note the downtrend in the income share of capital). For dominant capital, however, this was a period of spectacular differential gains, with their profitability rising many times faster than 
the economy's average, as well as the average for the Fortune 500 (note the logarithmic scale). In the second half of the 1980s, though, the tables turned. The overall economy, although still weak, seemed to have bottomed, whereas differential accumulation went into a nose dive. During the 1990s, the divergence became less pronounced, with both differential accumulation and overall growth rising toward the mid-1990s and then falling.

The contrast between overall economic performance and differential accumulation offers a shaper focus on both the nature and timing of the current U-turn in the two countries. As we emphasized earlier, in both cases the transformation was part of a long, complex process involving many factors. The final shift to the new order, though, was achieved through a relatively peaceful settlement among the elites, and it is here that dominant capital was crucial. Until the mid-1980s, this group, in both South Africa and Israel, faced two contradictory developments: a deepening political-economic turmoil on the one hand, and booming differential accumulation on the other. As indicated in the previous section, such divergence could not persist indefinitely. By the late 1970s, both cores were already large relative to their own economies, so at some point recession and falling profit were bound to cap their differential accumulation. But as long as that was not imminent, the temptation to squeeze as much as possible from the old order created an inevitable rift among the elites, pitting those concerned for the long term against others who benefited from the status quo. The crucial balance lay with differential accumulation. As long as its prospects looked reasonable, dominant capital remained indecisive or even hostile to change. But once it became evident that differential accumulation was running out of steam, dominant capital got off the fence, forcefully supporting the new order.

\section{The global context}

Why did differential accumulation in the two countries accelerate until the 1980s, and what brought its subsequent collapse? In our view, the main reason lies in the changing global position of the two countries. Most scholars dealing with the international context of South Africa and Israel tend to emphasize negative aspects such as international isolation, sanctions, armed conflict, and the Arab boycott. During the 1970s and 1980s, however, these negative influences have been more than offset by broader developments in the nature of global accumulation, whose implications for the two countries have been largely ignored.

Over the postwar period, differential accumulation in the industrialized countries moved from breadth to depth, and then back to breadth (Nitzan, 2001). During the 1950s and 1960s, the rebuilding of Europe and Japan was in some sense equivalent to the reproletarianization of their societies, acting as a powerful breadth engine. The consequence for the developed economies was rapid annual growth of around 6\% and low inflation of less than $3 \%$ (data in this paragraph are from the IMF). The picture was more or less inverted in the 1970s. With the German and Japanese miracles running out of steam, and with foreign investment in periphery countries still hindered by Communist or statist regimes, dominant capital groups in the West had to shift gear, moving their accumulation focus to depth. Overall growth dully tumbled to an annual average of $3 \%$, while inflation soared to $8 \%$. Stagflation during that period was a crisis for many, but for dominant capital groups, particularly those associated 
with energy, minerals, armament, and finance, it was a differential accumulation bonanza (Nitzan, 1992; Nitzan \& Bichler, 1995).

The late 1980s seem to mark the beginning of another shift. While inflation in the industrial countries has dropped drastically, growth has not revived to its postwar heights of the 1950s and 1960s. The absence of growth, though, is somewhat misleading. Indeed, for the Western core firms growth has not disappeared; it merely shifted outside the industrial countries. This shift, although not new, has been greatly accelerated by the collapse of the Soviet Union and the wholesale demise of statist ideology, which finally opened the entire world economy to capitalist expansion. Increasingly, dominant capital groups in the industrialized West have come to view emerging markets as their principal source of differential accumulation for the foreseeable future. During the early 1990s, US-based transnational companies derived over $20 \%$ of their total net earnings from developing countries, up from $10 \%$ a decade earlier (Nitzan, 1996b), and although this increase was recently dented by the crisis in Asia and Latin America, the general view is that the long-term uptrend is intact. Emerging markets offer not only rapid population growth, but most importantly an intense process of proletarianization. Moreover, because Western company penetration there is only now starting in earnest, their potential for differential accumulation remains vast. At the same time, the progressive liberalization of world trade and the incorporation of cheaper manufacturers into the transnational production circuit operate as a fanbelt, "cooling" Western inflationary pressures even further (Nakhjavani \& Nitzan, 1994; Nitzan, 1997).

In our view, these global shifts have greatly affected the broader trajectories of South Africa and Israel. The crucial global-domestic links are illustrated in Fig. 4, which shows a close correlation between inflation and the arms trade. The logic behind this connection comes from our hypothesis in the previous section, which suggested that social conflict is likely to be more heightened and overt in depth than in breadth. And, indeed, during the 1970 s and early 1980s, the inflationary depth regime in the Western countries was partly the consequence of bi-polar geopolitics, which not only prevented capitalist expansion into outlying areas, but also contested Western control over strategic regions, particularly the Middle East. One consequence of this antagonism was an intense arms race, and it is hence not surprising that arms exports roughly follow the periodicity of Western inflation. Both rose until the mid-1980s, peaked as the Cold War weakened, and went into a free fall with the disintegration of Communism and the movement toward global breadth.

This rise and fall of global inflation and arms exports were decisive for differential accumulation in South Africa and Israel, the first through its influence on gold, the second via its impact on the local war economy. We turn to consider these effects now, beginning with the old regime.

\section{The depth phase: gold and arms}

\subsection{South Africa}

The significance of gold for South African accumulation remains controversial. Nattrass (1992), for instance, emphasizes the increasingly central role of manufacturing, which she 


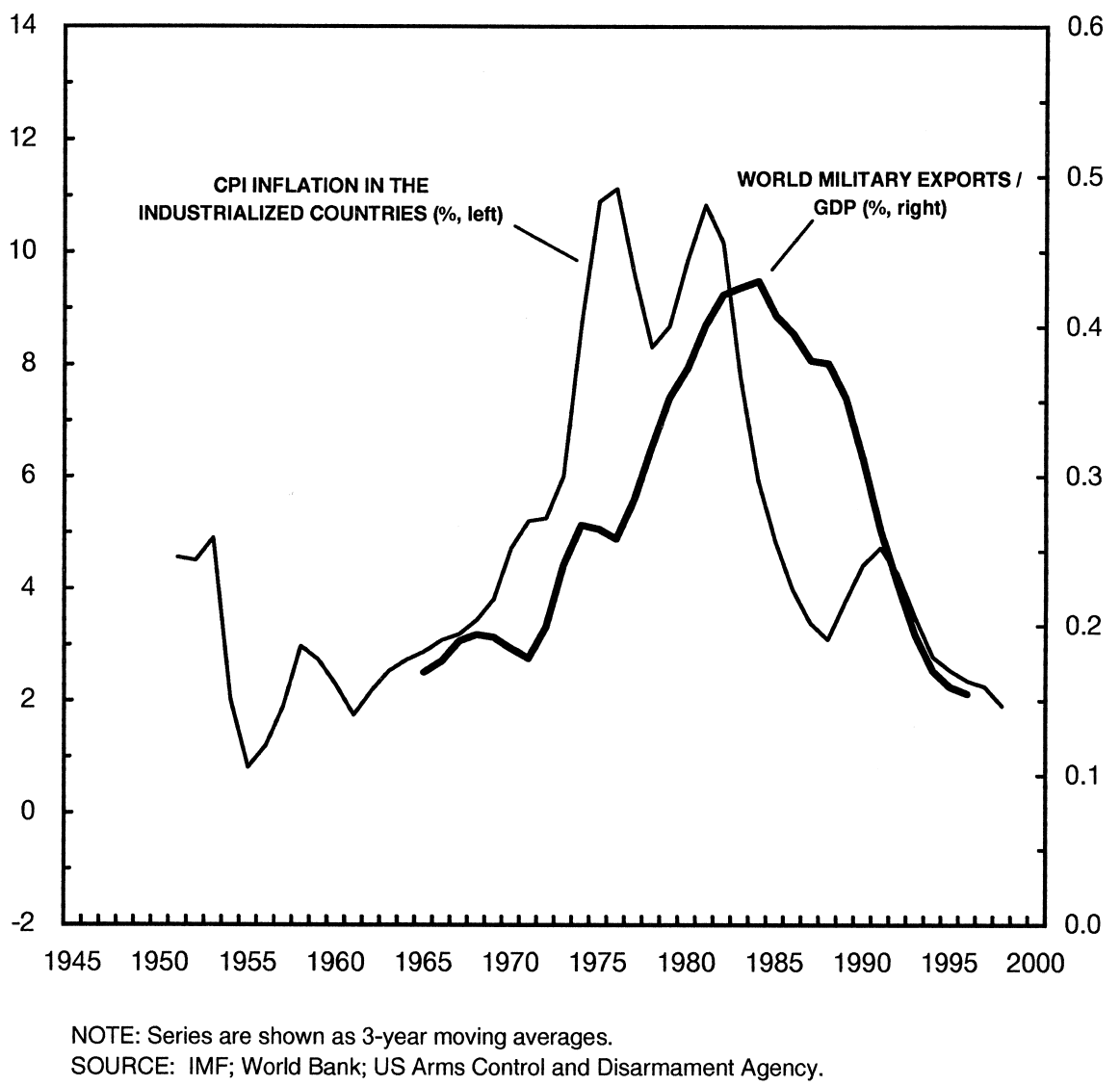

Fig. 4. Inflation and arms exports.

considers to be the economy's "leading sector." Manufacturing profits, she shows, were actually undermined by a rising wage share during the 1948-1989 period, thus contradicting the claim that apartheid acted as a mode of regulation or social structure of accumulation. This conclusion is unwarranted, however. As Fine and Rustomjee (1996) convincingly argue, the central axis of South Africa's political economy was and remained a "mineralenergy complex," or MEC, which they see not only as a core set of industries and institutions, but as a comprehensive system of accumulation. Industrialization and diversification emerged and continue to function as offshoots of this MEC. And, indeed, Nattrass's own data show that, unlike in manufacturing, the wage share in mining in fact fell over the 1948-1989 period. Moreover, the positive impact this had on overall profitability in the economy outweighed the negative impact of a rising wage share in manufacturing. In other words, although apartheid may have contributed to a profit squeeze in some sectors, its crucial achievement was to hold wages down in mining, and hence in the economy as a whole. ${ }^{6}$

The heart of the mining sector is gold, which according to Fine and Rustomjee (1996) generated, directly and indirectly, as much as $40 \%$ of South Africa's GDP. For our purpose, though, the more important question concerns the impact of gold on profitability, which we 


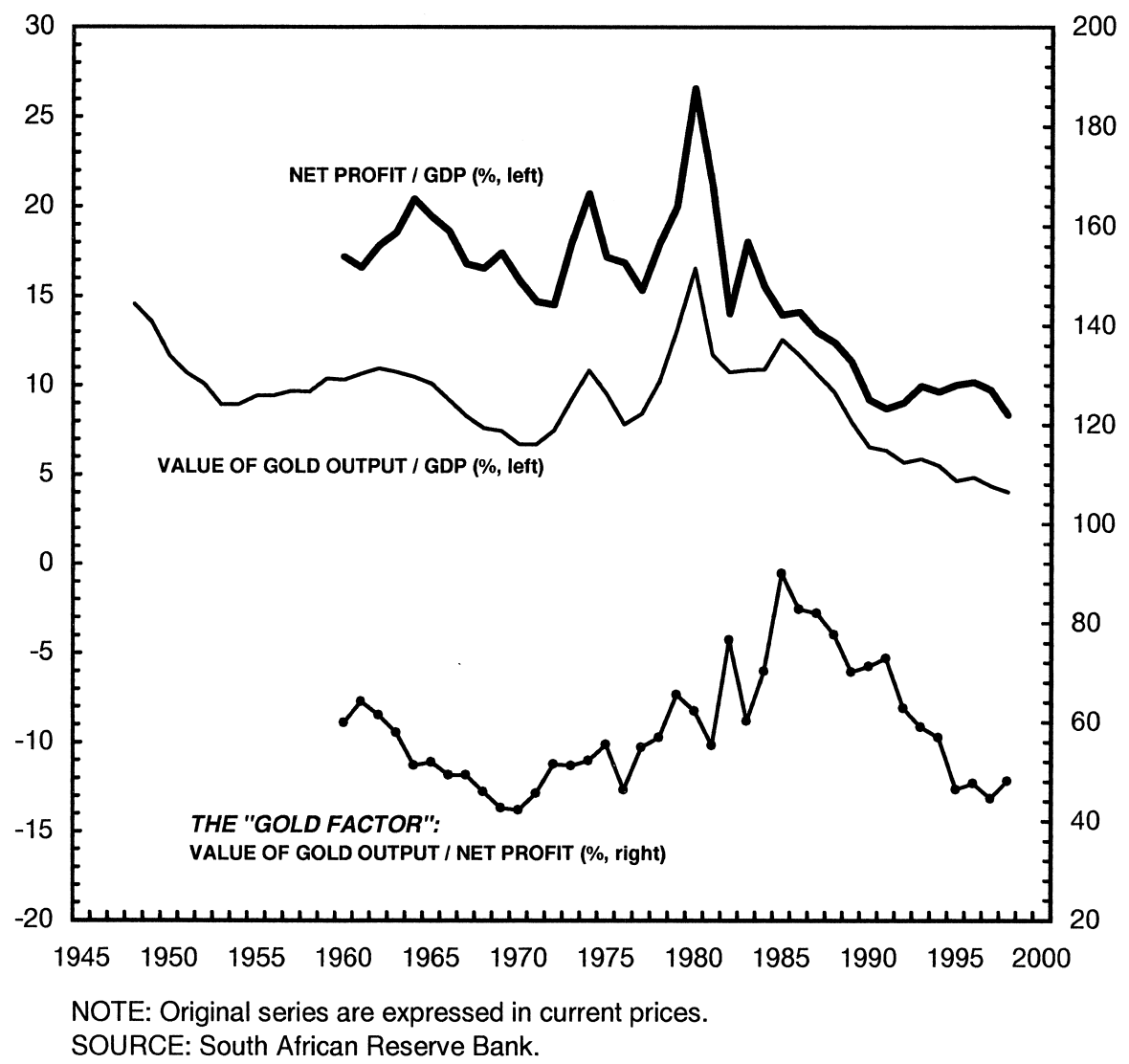

Fig. 5. South Africa's "gold factor."

illustrate in Fig. 5. Since 1960, the net profit share of GDP has fluctuated very much in tandem with the (direct) share of gold in GDP. The chart also shows the ratio between the value of gold output and net profit, labeled here as the "gold factor." Although not all gold revenues are appropriated as profit, the latter is the most volatile income component, so the ratio provides a rough idea about long-term changes in the relative significance of gold for profitability. The data suggest that with diversification during the boom years of the 1950s and early 1960s, the profit significance of gold was waning. But since the early 1970s, as South Africa was sliding deeper into crisis, the trend reversed, making gold ever more crucial for profit. Only in the latter half of the 1980s did the "gold factor" again start to decline.

The historical backdrop of these trends is charted in Fig. 6, which contrasts South Africa's gold production volume with the world price of gold (in US\$). During the first seventy years of this century, the price was fixed, first by the gold standard, and then by the dollar peg. In this context, South Africa's gold profit depended first on how much of the yellow metal it was able to produce, and, second, on its ability to keep production cost under control. Both of these factors hinged crucially on labor relations, and it was here that apartheid played a paramount role. Although labor is both a cost of production and a potential source of demand, in the gold sector, whose output is exported, only the former mattered. The main 


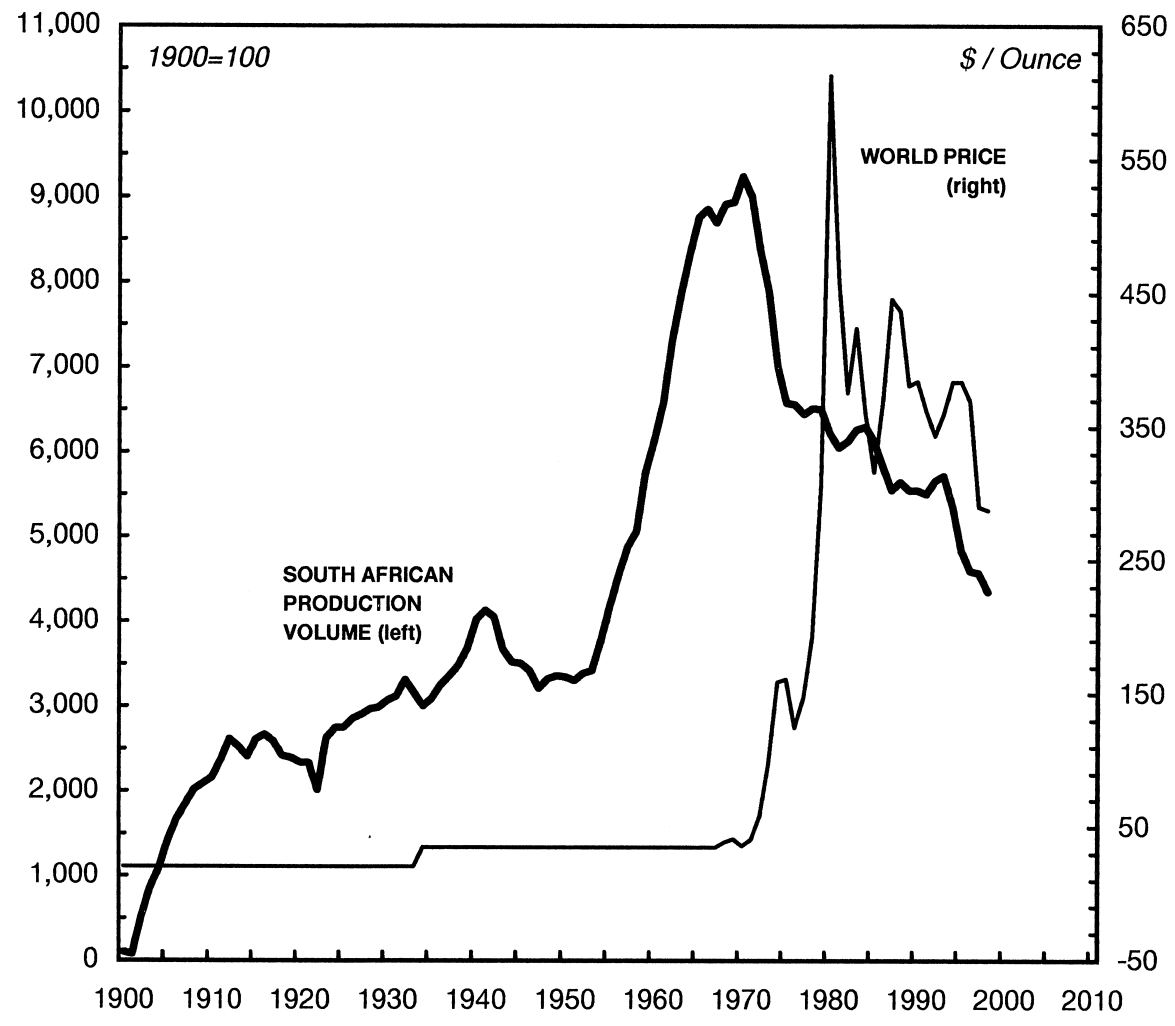

SOURCE: Innes (1984); IMF; Wall-Street Journal; South African Reserve Bank.

Fig. 6. Gold output and price.

task of apartheid here, in which it undoubtedly succeeded, was to assure a sufficient supply of labor, as well as to keep a tight lid over wages in order to sustain profit margins.

However, the progressive exhaustion of the more abundant mines, the general wage-pull driven by a growing economy, and the mounting cost of continuous racial conflict have made South African gold mining increasingly expensive by international standards. In the early 1970 s, South Africa's “century of gold" was coming to a close, as output began its long-term decline.

Yet for another whole decade, the impact on revenue and profit was largely invisible. The principal reason was the global shift from breadth to depth described in the previous section. Differential accumulation in the Western countries now hinged on an inflationary struggle over profit margins, and as world inflation started to accelerate, the price of gold-a traditional hedge against inflation-soared (gold and price inflation have been closely correlated since the collapse of Bretton Woods). The biggest winners were the large South African firms, which at the time accounted for over $75 \%$ of Western gold production. Between 1970 and 1980, South African gold output fell by a third, but with prices soaring, its overall value in \$US rose nearly twelve-fold.

This dual rise in inflation and gold prices must have been crucial for the future outlook of 
South Africa's dominant capital. To begin with, the gold boom boosted not only differential accumulation, but also the profit share and overall growth, thus raising the ceilings on future differential accumulation (Fig. 3). Most importantly, the situation was expected to continue. Although the large South African firms were well aware that their gold mines were maturing, until the early 1980s that seemed secondary. The general view was that world inflation would not only persist, but accelerate, which in turn implied ever-higher gold prices. And if gold prices were to go on rising, that would not only raise revenues and profit, but might also help reverse the very downtrend of production (by making marginal mines profitable). Clearly, this was hardly the time to emancipate black labor and give up control over the gold economy. The more enlightened members of the South African elites may have realized that such change was inevitable, and in the longer run, even desirable. But then with their differential accumulation progressing so nicely, the transition could wait a while longer.

The rude awakening came only after the early 1980s, with the end of the global depth phase. Commodity prices tumbled, emerging markets manufacturers began flooding the world with cheaper goods, and policy makers shifted their stance toward fiscal retrenchment and monetary restraint. Inflation, which only a decade ago seemed unstoppable, was rapidly falling, first in the Western countries, and subsequently also in the developing world. By the second half of the 1980s, it was becoming increasingly apparent that gold could no longer underwrite apartheid. Dominant capital continued to outperform, but only by being last in the race to the bottom. In a cyclical slump, the situation could have been tolerated, but this one was more like a meltdown, with overall profit falling by as much as two-thirds over the 1980s (in constant prices as well as a share of GDP). If this collapse were to continue-and there was nothing in the old regime to stop it-dominant capital would soon have had no average to beat. Clearly, it was time for change.

\subsection{Israel}

The Israeli core, much like its South African counterpart, also benefited from the global depth phase. The critical link here was the Middle East conflict, which, as noted earlier, was partly the consequence of superpower struggle over strategic outlying areas. The conflict was tied to global depth in yet another way: through the interests of a Weapondollar-Petrodollar coalition of large Western armament and oil companies operating in the region. With the rise of inflation since the early 1970s, differential accumulation by these companies was increasingly dependent on higher oil prices triggered by Middle East "energy conflicts" (Nitzan \& Bichler, 1995; Bichler \& Nitzan, 1996b).

Fig. 7 contrasts the Israeli core's differential accumulation with the influx of arms imports into the Middle East (expressed as a share of world GDP). On the face of it, the tight correlation between the two series until the late 1980s is surprising, to say the least. How could imports, of which the lion's share went to other countries in the region, affect the distribution of profit in Israel? And why was the correlation inverted over the past decade, with the core groups staging a differential comeback, this time despite the continuous drop of military shipments into the region? The answer is that the relationship was indirect.

Consider first the effect on differential accumulation of the regional arms boom. The most general impact operated through the militarization of the Israeli economy itself. The large 


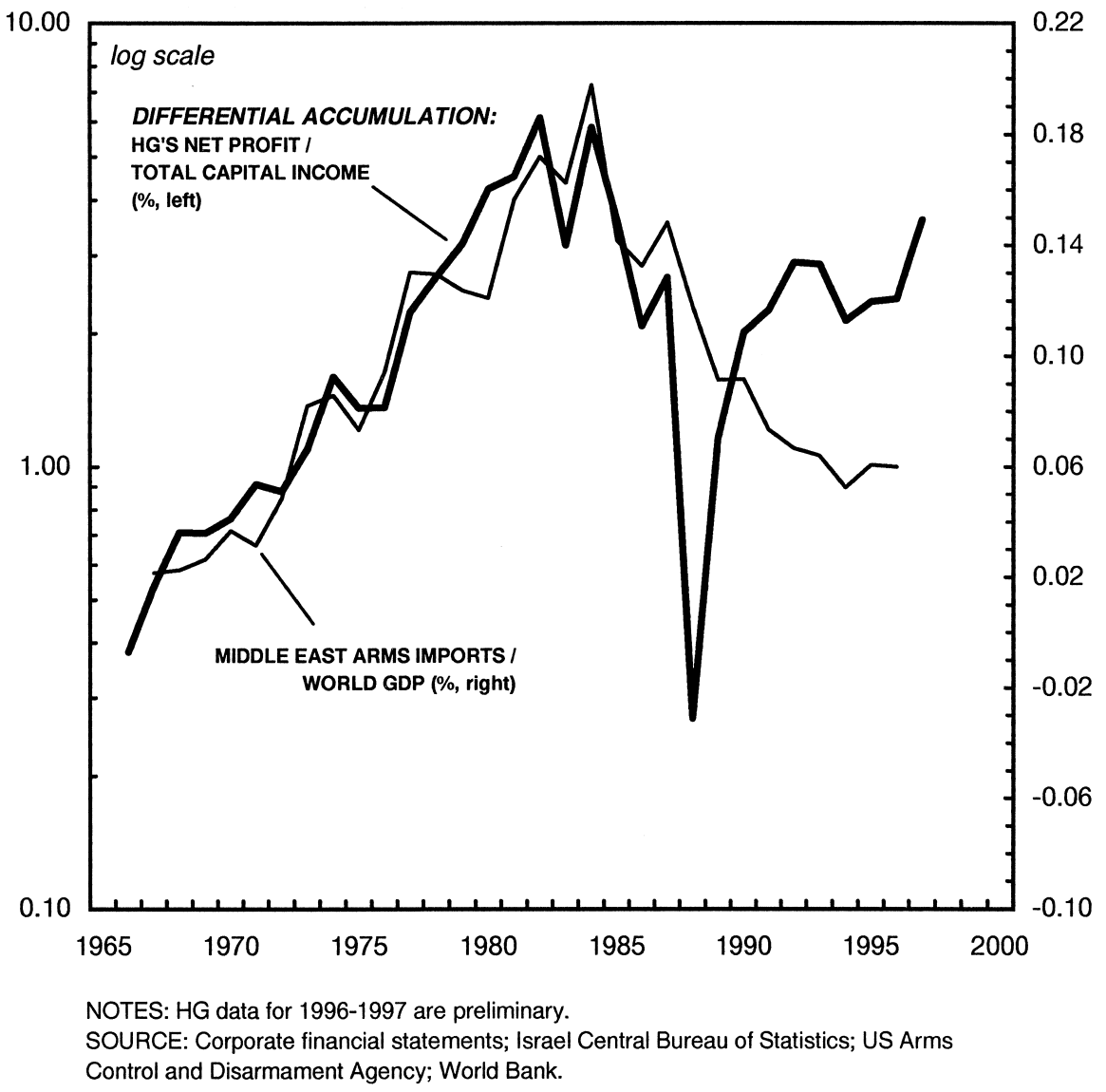

Fig. 7. Israeli differential accumulation and the Middle East arms race.

conglomerates were the principal beneficiaries of domestic military orders, as well as the largest weapon exporters (riding the global arms race fueled by superpower confrontation). And so, although military spending stifled the economy, particularly since the early 1970s, the effect on the core's differential accumulation was clearly positive (indeed, partly because the aggregate economy was stagnating). Another impact worked through US economic aid, which went hand-in-hand with its military assistance. Although the precise allocation of this money has never been made public, most of it was probably given to the large conglomerates through investment grants and subsidized credit (Bichler \& Nitzan, 1996a).

But the most significant impact of regional conflict, illustrated in Fig. 8, was to shift Israel itself from breadth to depth. Until the early 1970s, the core conglomerates were still in their formative stage, and their differential accumulation was accomplished mainly through the breadth route. Rapid population growth and massive capital transfers from Germany (in compensation for the Holocaust), helped sustain a prolonged economic boom, which was further augmented after 1967 by the proletarianization of over one million Palestinians in the newly occupied Arab territories. Together, these forces contributed directly to the external breath of differential accumulation, as well as indirectly to internal breadth by facilitating 


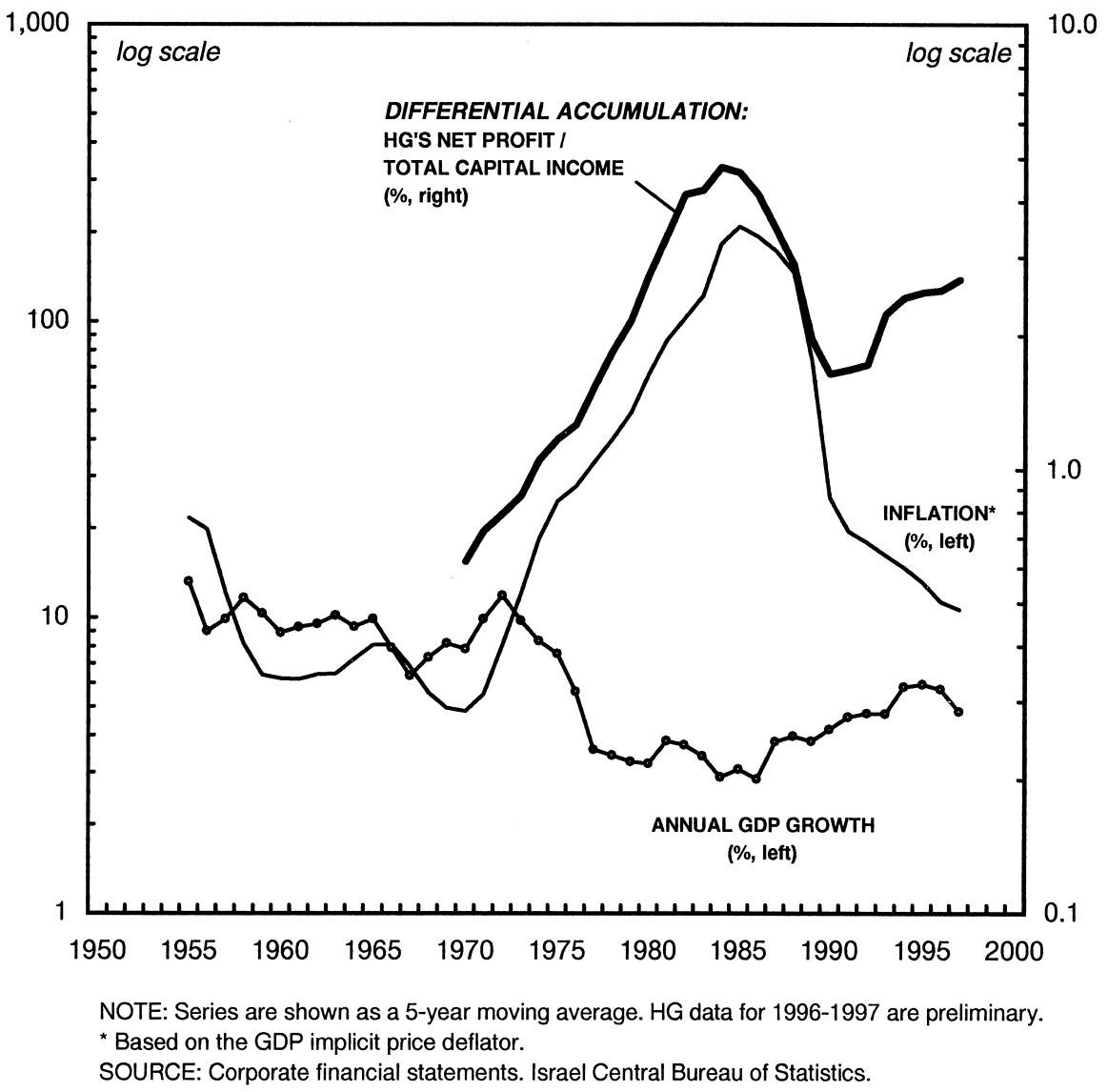

Fig. 8. Israeli stagflation and differential accumulation.

mergers. Inflation was relatively low, partly because the core firms lacked sufficient pricing power, as well as little reason to use it while seeking market share.

During the 1970s, in line with the global shift, the Israeli core moved from breadth to depth (Nitzan \& Bichler, 2000b). The external growth stimuli-unilateral capital inflow, population growth, and Palestinian proletarianization-were over. The core groups had the incentive to refocus on depth, and by now also enough business and political clout to achieve it. Their activity was rapidly shifting from civilian to military lines, and all of them were getting deeper into a coordinated stock-rigging scheme which was to amplify their profit manifold, before crashing in 1983.

Given that Israel was functioning as a regional stronghold for Western interests, the United States did not insist on liberalization and deregulation as a precondition for aid. For the local core groups, the benefit was therefore twofold: not only did they enjoy US aid and the military boom, but they were also sheltered from domestic and import competition. The net result, depicted in Fig. 8, was that as economic growth tumbled and inflation skyrocketed, the core groups saw their profits soar and their differential accumulation reaching new heights. Clearly, much like in the South African case (although for different reasons), until 
the mid-1980s Israel's dominant capital had a good reason not to reconsider its regional situation. After all, it was the regional conflict which contributed most to its spectacular differential performance.

But no matter how potent in the short term, the depth route cannot fuel differential accumulation indefinitely; military budgets cannot increase without eventually suffocating the economy, while in the context of protracted stagnation, inflationary redistribution is bound to create mounting social unrest. The end of the depth regime was first signaled by the stock market crash of 1983, followed by the 1985 imposition of price controls, the decline of domestic military budgets, and the sharp drop in global demand for weapons. The core's profit share of GDP collapsed, and the depth phase was brought to a close.

\subsection{External pressure, internal struggle, and the end of depth}

A depth regime like the one experienced in South Africa and Israel during the 1970s and 1980 s is inherently conflictual, turbulent, unstable, and difficult to manage. From the apex viewpoint of dominant capital, however, this social context is reified through the bottom line. Strikes, uprisings, isolation, sanctions, or war-much like military spending, inflation, and gold prices - are important not for what they are, but through their expected impact on future profit. This "capitalist calculus of pleasure and pain," the incessant quantification and reduction of social attitudes, institutions, and processes down to their "present value" and "risk premia," is the essence of the commodification of power as capital. For dominant capital, and hence for the purpose of our analysis here, the key question therefore is not the nature of social conflict per se, but the extent to which such conflict affects capitalist power, crystallized in the process of differential accumulation.

Since the 1960s, South Africa was subject to increasing international pressure to abandon or at least reform apartheid. The most explicit form of this pressure was international sanctions, which began in the 1960s, intensified in the 1970s, and reached their (moderate) climax with the transnational divestment movement of the 1980s (Lipton, 1988). Sanctions acted as an external constraint on South Africa's overall growth. They also restricted (but not prevented) capital outflows. The key question, though, is how this pressure affected the country's elite, particularly dominant capital, and here the picture is mixed. First, although international isolation has gradually undermined the elite's self-confidence and sense of legitimacy, until the late 1980s many of this elite still believed that "when it comes to the crunch" the United States and Great Britain will support their regime because of its anti-Communist stand (Sampson, 1987: 215). Second, sanctions have in fact boosted differential accumulation by curtailing import competition, by allowing local dominant capital to take over transnational assets, and by doing nothing to limit the export of gold.

International isolation was far less significant in the case of Israel, which continued to enjoy massive military aid, economic assistance, and free access to European and North American markets. Moreover, although its long occupation of Arab land and population remains in violation of UN resolutions, so far these resolutions have not been enforced. In fact, Israel has managed to retain the overt or tacit support of many Western governments, which see it as a liberal, democratic island in the midst of hostile backwardness. Until the late 1980s, Israel willingly acted as the main anti-Communist bulwark in the region (Orr \& 
Machover, 1999), and now, with the Soviet menace gone, it eagerly participates in US attempts to contain Islamic fundamentalism.

The main socio-political similarity of the two depth regimes was that they both ended in the turmoil of popular uprising: the black revolt in South Africa and the Intifada in the occupied Palestinian territories. Although these uprisings were rooted in long struggles for racial equality and national independence, the fact that they erupted in the 1980s was partly a consequence of the depth phase itself. In South Africa, the collapsing economy during the 1980s reversed the earlier trend of rising employment and wages, bringing massive layoffs and plummeting wages; similarly in the occupied territories, where Israel's shift into depth sharply curtailed demand for Palestinian workers. During the 1970s and early 1980s, many of these workers found jobs in the Persian Gulf, but as the oil boom receded, their return home caused unemployment and social pressure to soar.

For dominant capital, these pressures, particularly the internal struggles, were certainly costly, and as such contributed to the end of the depth regime. In our view, however, the crucial consideration, particularly with respect to the timing of the U-turn, had to do with the far more volatile benefits - namely gold earnings and war profits. Although the cost of depth mounted steadily since the 1970s, until the mid-1980s its impact on differential accumulation was outweighed by soaring benefits. It was only when global changes caused these benefits to collapse that the attendant cost became too heavy to bear.

The implication of this logic is twofold. First, it suggests that in both cases the U-turn was a consequence of structural global forces as well as organized struggle. Second, it helps explain the relatively peaceful nature of both transitions. Indeed, if instead of abating, superpower confrontation and global inflation were to continue, the benefit for dominant capital in the two countries would have remained large, making the cost of oppression look manageable. Under these latter circumstances, the U-turns would have been far more violent and possibly far from over.

\section{Going global: toward a new breadth phase?}

One of the key consequences of the U-turn in the two countries is the transnationalization of their dominant capital, in terms of both ownership and accumulation. Until recently, the core groups were largely domestically owned, focused on augmenting their power in their own countries. Their differential accumulation was greatly affected by global conditions, but this impact was external and indirect. Since the 1990s, the situation changed fundamentally, in that the very definition of these cores, as well as their accumulation basis, have grown increasingly global.

Although this change is part of a broader process of capitalist globalization and integration, it is nonetheless different from developments in most other semiperiphery countries. Whereas the latter mostly "open up" to inward foreign investment, South Africa and Israel seem to also "open out" to capital flight. The main reason for this difference is the much larger size of dominant capital in the two countries, which after years of heightened differential accumulation, has grown "too big" for their own economies. Under these 
circumstances, the only way to continue and accumulate differentially is to break the domestic "envelope," moving into a larger accumulation universe (Nitzan, 2001).

Consider the options available for dominant capital at the end of their depth phase. Increasing global pressure for external liberalization and internal market reform made renewed inflation (depth/external) impossible. Significant wage erosion (depth/internal) was equally impractical, particularly in South Africa where this would have spelled social upheaval. Mergers and acquisitions (breadth/internal) were feasible, but given the already high level of corporate concentration in the two countries, largely ineffective as a differential accumulation vehicle. The only open avenue was expanding control over new production (breadth/external). This happened in Israel during the "seven good years" of 1990-1997, when massive immigration of over 700,000 Jews from the Commonwealth of Independent States provided fresh grounds for differential accumulation. But the process was inherently temporary, and when it came to an end, so did economic growth. The potential for further external breadth in South Africa, where roughly half the population is still rural and yet to be proletarianized, remains large, at least in principal (the comparable figure in Israel is less than $10 \%$ ). For the time being, though, this potential is capped by lingering racial conflict, massive crime, growing corruption, and an AIDS epidemic. Under these conditions, the only avenue for differential accumulation is to expand breadth outside the country, where profit growth, although difficult, is potentially vast.

And this is where the great U-turn comes in. If dominant capital were to expand beyond the country's border, capital movement had to be made free, which in turn suggests why the core groups in the two countries suddenly moved to support the new order. The reason is prosaic. In South Africa, apartheid brought international sanctions and relentless pressure on the current account, which the authorities had to counteract by restricting capital outflow. Although capital controls were never complete (to say the least), they nonetheless hindered the international diversification of South African capitalists. This is clearly evident from the share of corporate profit originating from outside the country, which during the 1990s was roughly $7 \%$, only marginally higher than during the 1960s. For comparison, US corporations during the 1990s earned almost 30\% of their profit abroad, up from 10\% in the 1960s (data from the South African Reserve Bank and the US Department of Commerce). A similar situation prevailed in Israel, where the security situation and the Arab boycott limited the extent of private capital inflow. Although this was partly offset by US government assistance, here too the authorities were forced to maintain capital controls, thus holding back on foreign diversification by domestic firms. In both cases, therefore, capital controls were rooted in the underlying political regime; if these controls were to go, the political regimes themselves had to first be dismantled.

Developments during the 1990s seem to confirm this logic. The "new South Africa" trajectory is largely a three-way pact between the ANC, COSATU (the unions), and dominant capital. In this new setting, the ANC abandons its earlier statist/socialist stance, accepting the imperative of globalization, liberalization, and the primacy of private investment in return for "black empowerment." COSATU, faced with the threat of rising import competition while having to cope with massive unemployment (estimated at 30-40\%), agrees to an industrial-relations truce in return for moderate wage hikes. And dominant capital accepts the need to unbundle its oligopolistic "stranglehold" over the economy 
(selling parts of it to black entrepreneurs, including the unions) in return for gradual capital decontrols and the ability to diversify abroad.

A similar arrangement emerges in Israel. The heart of the new political order is mutual recognition of the legitimacy of Israel and the right of the Palestinian people for selfdetermination. Although this recognition remains far from true peace, it has already yielded large "peace dividends," particularly for Israel's dominant capital. De-colonization of the occupied territories, however partial, hesitant, and hampered by setbacks, helps defuse the broader Israeli-Arab conflict, making Israel look as if it is finally on the way toward regional integration. This mere appearance of normality was already enough to have foreign investors flocking in. FDI inflow soared from negative levels in the late 1980s to 3.5\% of GDP in 1997-their highest rate since 1965. As the currency gained strength, most capital controls were removed. The door was finally open for the first meaningful FDI outflow in Israel's history, which during the mid-1990s rose to nearly 1\% of GDP (data from Israel Central Bureau of Statistics). So far, little of this outflow has gone to Middle East countries, which are both too poor and still hostile to Israel (Sagi \& Sheinin, 1994). In this sense, regional reconciliation is largely a means; the real end-at least for the time being-is to diversify away from the region.

In both countries, outward corporate expansion involves a fundamental transformation of the very nature of dominant capital. First, the previous conglomerate structure is giving way to a more "flat" ownership pattern. Anglo American Corporation, for instance, began to disentangle its complicated cross-ownership ties, divesting some of its holdings and reorganizing the rest into five distinct subsidiaries with clear business foci. The rationale behind this deconglomeration, evident in other large corporations in the two countries, is to strengthen their ability to expand outside their own borders.

The second, more crucial, aspect of this transformation is a change in ownership, affecting the very definition of the core. Successful outward investment requires market and political leverage which even the largest South African and Israeli corporations lack, and which they hope to obtain by integrating into the orbit of global dominant capital. Although the boundaries of this global group and the identity of its members remain in flux, the unprecedented current wave of cross-border mergers and acquisitions leaves little doubt that such core is indeed in the making. The large Israeli companies have been busy forging ownership ties with global giants since the early 1990s. Their South African counterparts, although a little slower, are catching up. Recently, many of them moved their primary stock market listings from Johannesburg to London, preparing the way for new transnational alliances.

Under these new circumstances, it is increasingly difficult to speak about the "South African" or "Israeli" core. Instead, we have a process by which South African and Israeli capitalists become global absentee owners, part of a transnational capitalist class, as the neo-Gramscians call it, whose differential power claims seek to transcend all geographical boundaries. From this viewpoint, the sharp rebounding of differential accumulation during the 1990s in Figs. 3 and 4 is somewhat misleading. In both countries, the core is now increasingly absorbed into a broader global amalgamate, whose source of profit as well as the benchmark it tries to beat are worldwide in scope. 
The irony of the new situation is that such outward expansion nonetheless serves to bolster the domestic power of dominant capital. Whereas previously this power was supported by direct political leverage, now it is repackaged into a broader, seemingly amorphous though equally imposing entity known as the "global market." The evidence for this is not hard to find. The Likud government of 1996-1999, supported by wide strata for whom the new trajectory of "peace dividends" was a real threat, halted the peace process but did not dare to reverse it. The subsequent Labor government, more attuned to the preferences of global capital, put it back on its shaky tracks. In South Africa, the ANC government, bending over backwards to "the market," shifted its stance from a Keynesian Reconstruction and Development Program (RDP), to a supply-side Growth, Employment, and Redistribution policy (GEAR), hoping for investment-led growth. Such investment, though, is now flowing not into but out of the country.

\section{Notes}

1. The analytical framework of differential accumulation is articulated in Nitzan (1998) and Nitzan and Bichler (2000a). The concept of differential accumulation was first introduced in Nitzan (1992) where it was used as a basis for understanding inflation as a process of corporate restructuring. The significance of differential accumulation for international political economy, with special emphasis on energy conflicts in the Middle East, is analyzed in Nitzan and Bichler (1995) and Bichler and Nitzan (1996b). An analytical model and econometric analysis of differential accumulation in Israel during its militaristic stage is given in Bichler and Nitzan (1996a). The role of differential accumulation for the Israeli U-turn is examined in Nitzan and Bichler (1996). The relationship between inflation and differential accumulation is developed in Nitzan and Bichler (2000b). Nitzan (2001) offers a general framework for understanding differential accumulation regimes, using it to examine the historical interaction between corporate amalgamation, crisis and globalization in the twentieth century.

2. The insight of Veblen is again illuminating. "In all these civilized countries where the price system has gone into effect," he writes, "men count their wealth in money-values. So much so that by settled habit. . . men have come to the conviction that money-values are more real and substantial than any of the material facts in this transitory world. . . and when a person has sold his goods, and so becomes in effect a creditor by that much, he is said to have 'realized' his wealth, or to have 'realized' his holdings." Paradoxically_-though not surprisingly_-"[i]n the business world the price of things is a more substantial fact than the things themselves" (1923: 88-9, emphasis added).

3. The distinction between profit and capital is often reconciled by revaluating capital at current or replacement cost, but that creates more problems than it solves. The effect is not only to undermine capital's existence as material wealth or "dead" labor, but also to introduce potential circularity into the measured rate of return, since current capital values (as opposed to historical values) constantly adjust to reflect current profits.

4. For a slightly different decomposition, which associates breadth with employment 
growth and depth with the growth of profit per employee, see Nitzan \& Bichler (2000b), and Nitzan (2001).

5. A simple linear regression for the industrialized countries over the 1949-1998 period, in which annual consumer price inflation is a function of a constant and the annual rate of change of industrial production, yields the following coefficient estimates and $R^{2}$ respectively: -0.6 and 0.21 for data smoothed as 5-year moving averages, -0.8 and 0.30 with 10 -year moving averages, -0.9 and 0.39 with 15 -year moving averages, and -0.9 and 0.52 with 20-year moving averages. The long-term relationship between inflation and growth is unequivocally negative and grows tighter with longer smoothing (based on IMF data).

6. The overall profit rate nonetheless fell, but that was due to declining economic growth and a consequent downtrend in the output/capital ratio, which more than offset the rising profit share.

\section{Acknowledgments}

Jonathan Nitzan teaches at the Department of Political Science, York University, Canada. Shimshon Bichler teaches at colleges and universities in Israel. The gist of our argument first appeared in Nitzan $(1995 ; 1996 a)$ and Bichler and Nitzan (1995). We wish to thank Stephen Gill, Kamran Nayeri, John Willoughby, and Behzad Yaghmaian for their insightful comments. Research for this paper was partly supported by an SSHRC grant.

\section{References}

Aharoni, Y. (1976). Structure and performance in the Israeli economy. Hebrew. Tel Aviv: Cherikover. Barnaby, F. D. (1989). The invisible bomb: the nuclear arms race in the Middle East. London: I.B. Tauris.

Barnet, R. J. (1972). Roots of war. The men and institutions behind U.S. foreign policy. New York: Atheneum Publishers.

Beith Hallahmi, B. (1987). The Israeli connection. New York: Pantheon Books.

Bichler, S. (1991). The political economy of military spending in Israel. Unpublished Doctoral Dissertation. Department of Political Science. Hebrew University. Jerusalem.

Bichler, S., \& Nitzan, J. (1995). The great U-turn: restructuring in Israel and South Africa. News From Within, $X I$ (9), September: 29-32.

Bichler, S., \& Nitzan, J. (1996a). Military spending and differential accumulation: a new approach to the political economy of armament - the case of Israel. Review of Radical Political Economics, 28 (1), 52-97.

Bichler, S., \& Nitzan, J. (1996b). Putting the state in its place: US foreign policy and differential accumulation in Middle-East energy conflicts. Review of International Political Economy, 3 (4), 608-661.

Böhm-Bawerk, E. V. (1923). The positive theory of capital. New York: Stechert.

Clark, J. B. (1899, 1965). The distribution of wealth. New York: Augustus M. Kelley.

Davies, R., Kaplan, D., Morris, M., \& O'Meara, D. (1976). Class struggle and the periodisation of the state in South Africa. The Review of African Political Economy, 7, 4-30.

Elmessiri, A. M. (1976). Israel and South Africa: a link matures. In: P. R. Stevens \& A. M. Elmessiri (Eds.), Israel and South Africa. The progression of a relationship. New York: New World Press. 
Farjoun, E. (1978). The Palestinian workers-an economic reserve army. Hebrew Red Papers, 5, Jerusalem. Farjoun, E. (1980). The Palestinian workers in Israel—a reserve army of labour. Khamsin, 7, 107-143. London. Fine, B., \& Rustomjee, Z. (1996). The political economy of South Africa. From minerals-energy complex to industrialization. London and Boulder, Col.: Westview Press.

Gardiner, K., \& Rösgen, M. (1996). South Africa: growth holds the key. Morgan Stanley. Emerging Markets Investment Research, June 10.

Gelb, S. (1987). Making sense of the crisis. Transformation, 5, 33-50.

Gozansky, T. (1986). The formation of capitalism in Palestine. Hebrew. Haifa: Mifalim Universitaim.

Greenberg, S. (1980). Race and state in capitalist development: comparative perspectives. New Haven: Yale University Press.

Greenstein, R. (1995). Genealogies of conflict. Class, identity and state in Palestine/Israel and South Africa. Hanover and London: Wesleyan University Press. Published by University Press of New England.

Harcourt, G. C. (1972). Some Cambridge controversies in the theory of capital. Cambridge: Cambridge University Press.

Howard, M. C., \& King, J. E. (1992). A history of Marxian economics. Volume II, 1929-1990. Princeton, NJ: Princeton University Press.

Huntington, S. P. (1993). The clash of civilizations? Foreign Affairs, 72 (3), Summer: 22-49.

Innes, D. (1984). Anglo American and the rise of modern South Africa. New York: Monthly Review Press.

Johnstone, F. (1970). White prosperity and white supremacy in South Africa today. African Affairs, 69 (275), $124-140$.

Kimmerling, B. (1983). Zionism and territory. The socio-territorial dimensions of Zionist politics. Berkeley: University of California Press.

Kotz, D. M. (1994). The regulation theory and the social structure of accumulation. In: D. M. Kotz, T. McDonough, \& M. Reich (Eds.), Social structures of accumulation. The political economy of growth and crisis. Cambridge: Cambridge University Press.

Kuper, L. (1971). Plural societies: perspectives and problems. In: L. Kuper \& M. G. Smith (Eds.), Pluralism in Africa. Berkeley: University of California Press.

Legassick, M. (1974). South Africa: capital accumulation and violence. Economy and Society, 3 (1), 253-285. Lipton, M. (1985). Capitalism and apartheid. South Africa, 1910-84. Totowa, NJ: Rowman \& Allanheld.

Lipton, M. (1988). Sanctions and South Africa. The dynamics of economic isolation, Special Report 1119. London: The Economist Intelligence Unit.

Marshall, A. (1920). Principles of economics. An introductory volume (8th ed.). London: Macmillan.

McTague, J. (1985). Israel and South Africa: a comparison of policies. Journal of Palestinian Studies, 14, Spring.

Mumford, L. (1967). The myth of the machine. Technics and human development. New York: Harcourt, Brace \& World, Inc.

Mumford, L. (1970). The myth of the machine. The pentagon of power. New York: Harcourt, Brace Jovanovich, Inc.

Nakhjavani, M., \& Nitzan, J. (1994). From freewheel to fanbelt: the growing importance of emerging markets. Emerging Markets Analyst, 3 (8), December: 6-12.

Nattrass, N. (1989). Post-war profitability in South Africa: a critique of regulation analysis in South Africa. Transformation, 9, 66-80.

Nattrass, N. (1992). Profitability: the soft underbelly of South African regulation/SSA analysis. Review of Radical Political Economics, 24 (1), 31-51.

Nitzan, J. (1992). Inflation as restructuring: a theoretical and empirical account of the U.S. experience. Unpublished Doctoral Dissertation. Department of Economics. McGill University. Montreal.

Nitzan, J. (1995). The political economy of peace. Emerging Markets Analyst, 3 (9), January: 9-10.

Nitzan, J. (1996a). Israel and South Africa: prospects for their transitions. Emerging Markets Analyst, 4 (10), February: $12-18$.

Nitzan, J. (1996b). US-based transnational corporations and emerging markets. Emerging Markets Analyst, 5 (3), July: $12-24$. 
Nitzan, J. (1997). The "Asian miracle": how close to maturity? The BCA Emerging Markets Strategist, November, 5-10.

Nitzan, J. (1998). Differential accumulation: toward a new political economy of capital. Review of International Political Economy, 5 (2), 169-216.

Nitzan, J. (2001, forthcoming). Regimes of differential accumulation. Mergers, stagflation and the logic of globalization. Review of International Political Economy, 8 (2).

Nitzan, J., \& Bichler, S. (1995). Bringing capital accumulation back in: the weapondollar-petrodollar coalitionmilitary contractors, oil companies and Middle-East "energy conflicts." Review of International Political Economy, 2 (3), 446-515.

Nitzan, J., \& Bichler, S. (1996). From war profits to peace dividends-the new political economy of Israel. Capital \& Class, 60, 61-94.

Nitzan, J., \& Bichler, S. (2000a). Capital accumulation: breaking the dualism of "economics" and "politics". In: R. Palan (Ed.), Global political economy: contemporary theories, New York and London: Routledge.

Nitzan, J., \& Bichler, S. (2000b). Inflation and accumulation: the case of Israel. Science \& Society, 64 (1): $274-309$.

Olson, M. (1965). The logic of collective action. Public goods and the theory of groups. Cambridge, Mass: Harvard University Press.

Olson, M. (1982). The rise and decline of nations. Economic growth, stagflation and social rigidities. New Haven and London: Yale University Press.

Orr, A., \& Machover, M. (1999). Peace, peace and there is no peace. Hebrew. (2nd ed.). Jerusalem: n.p. (First published in 1961).

Poulantzas, N. (1975). Class in contemporary capitalism. London: New Left Books.

Ramos, M., \& Cassim, F. (1989). Beyond dependency: peripheral Fordism in South Africa. Paper presented at the Lausanne Colloquium, University of Lausanne. July.

Rosenfeld, H. (1979). The class situation of the Arab national minority in Israel. Hebrew. Notebooks for Research and Criticism, 3, Haifa.

Rowley, J. C. R., Bichler, S., \& Nitzan, J. (1988). Some aspects of aggregate concentration in the Israeli economy, 1964-1986. Working Paper 7/88. Department of Economics. McGill University. Montreal.

Sagi, E., \& Sheinin, Y. (1994). Opportunities for trade with Arab countries. Hebrew. The Economic Quarterly, 41 (1), 15-27.

Sampson, A. (1987). Black and gold. Tycoons, revolutionaries and apartheid. New York: Pantheon Books.

Schumpeter, J. A. (1954). History of economic analysis. Ed. from manuscript by E. B. Schumpeter. New York: Oxford University Press.

Schumpeter, J. A. (1955). Imperialism and social classes. Introduction by Bert Hoselitz, Translated by Heinz Norden. New York: Meridian Books.

Shafir, G. (1989). Land, labor and the origins of the Israeli-Palestinian conflict, 1882-1914. Cambridge: Cambridge University Press.

Shaikh, A. (1990). Capital as a social relation. In: J. Eatwell, M. Milgate, \& P. Newman (Eds.), The new Palgrave. Marxian economics. New York and London: W.W. Norton \& Company.

Smooha, S., \& Hanf, T. (1992). The diverse modes of conflict-regulation in deeply divided societies. International Journal of Comparative Sociology, 33 (1-2), 26-47.

Steedman, I. (1975). Positive profits with negative surplus value. Economic Journal, 85, 114-123.

Steedman, I. (1977). Marx after Sraffa. London: New Left Books.

Stevens, P. R. (1976). Smuts and Weizmann. In: P. R. Stevens \& A. M. Elmessiri (Eds.), Israel and South Africa. The progression of a relationship. New York: New World Press.

Tsuru, S. (1993). Institutional economics revisited. Cambridge: Cambridge University Press.

Tuchman, B. W. (1984). The march of folly. From Troy to Vietnam. New York: Alfred A. Knopf.

Veblen, T. (1904, 1975). The theory of business enterprise. Clifton, NJ: Augustus M. Kelley, Reprints of Economics Classics.

Veblen, T. (1908a). On the nature of capital. I: The productivity of capital goods. Reprinted in Veblen, 1919. 
Veblen, T. (1908b). On the nature of capital. II: Investment, intangible assets, and the pecuniary magnate. Reprinted in Veblen, 1919.

Veblen, T. $(1919,1961)$. The place of science in modern civilisation and other essays. New York: Russell \& Russell.

Veblen, T. (1923, 1967). Absentee ownership and business enterprise in recent times. The case of America. With an introduction by Robert Leckachman. Boston: Beacon Press.

Wright, E. O. (1977). Alternative perspectives in Marxist theory of accumulation and crisis. In: J. Schwartz (Ed.), The subtle anatomy of capitalism. Santa Monica: Goodyear. 